\title{
MASTER
}

\section{A Preliminary Screening of Thermal Storage Concepts for Water/ Steam and Organic Fluid Solar Thermal Receiver Systems}

Robert J. Copeland Michael E. Karpuk Jane UIIman
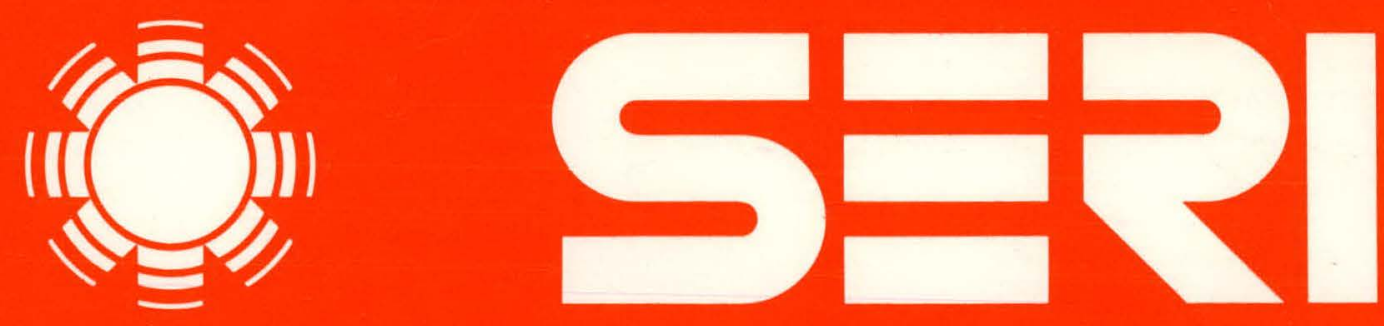

Solar Energy Research Institute A Division of Midwest Research Institute

1617 Cole Boulevard

Golden, Colorado 80401

Operated for the U.S. Department of Energy under Contract No. EG-77-C-01-4042 


\section{DISCLAIMER}

This report was prepared as an account of work sponsored by an agency of the United States Government. Neither the United States Government nor any agency Thereof, nor any of their employees, makes any warranty, express or implied, or assumes any legal liability or responsibility for the accuracy, completeness, or usefulness of any information, apparatus, product, or process disclosed, or represents that its use would not infringe privately owned rights. Reference herein to any specific commercial product, process, or service by trade name, trademark, manufacturer, or otherwise does not necessarily constitute or imply its endorsement, recommendation, or favoring by the United States Government or any agency thereof. The views and opinions of authors expressed herein do not necessarily state or reflect those of the United States Government or any agency thereof. 


\section{DISCLAIMER}

Portions of this document may be illegible in electronic image products. Images are produced from the best available original document. 
Printed in the United States of America Available from:

National Technical Information Service

U.S. Department of Commerce

5285 Port Royal Road

Springfield, VA 22161

Price:

Microfiche $\$ 3.00$

Printed Copy $\$ 5.25$

7.2

NOTICE

This report was prepared as an account of work sponsored by the United States Government. Neither the United States nor the United States Department of Energy, nor any of their employees, nor any of their contractors, subcontractors, or their employees, makes any warranty, express or implied, or assumes any legal liability or responsibility for the accuracy, completeness or usefulness of any information, apparatus, product or process disclosed, or represents that its use would not infringe privately owned rights. 
A PRELIMINARY SCREENING

OF THERMAL STORAGE CONCEPTS

FOR WATER/STEAM AND

ORGANIC FLUID SOLAR THERMAL

RECEIVER SYSTEMS
R. J. COPELAND
M. E. KARPUK
J. L. ULLMAN

APRIL 1980

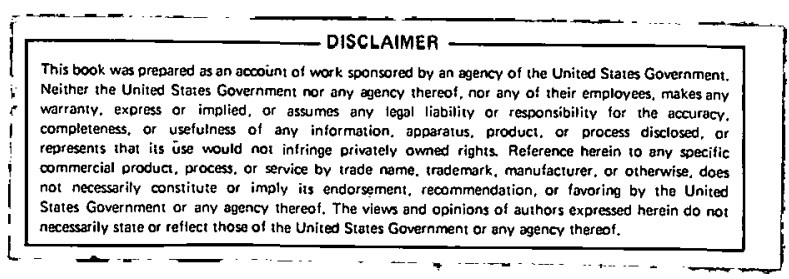

PREPAREd UNDER TASK No. 3528.10

\section{Solar Energy Research Institute}

A Division of Midwest Research Institute

1617 Cole Boulevard

- Golden, Colorado $\mathbf{8 0 4 0 1}$

Prepared for the

U.S. Department of Energy

Contract No. EG-77-C-01-4042 
THIS PAGE

\section{WAS INTENTIONALLY \\ LEFT BLANK}




\section{PRER ACE}

To facilitate the accelerated development of thermal energy storage technologies for solar thermal systems, a comprehensive program plan has been drafted. The plan was prepared at the joint request of the DOE Divisions of Central Solar Technology and Energy Storage Systems. The objective of the program is to provide thermal storage subsystems offering cost/performance improvements over currently available technologies. SERI is supporting the implementation of the plan with systems analysis.

The systems analysis activity consists of both value analyses and a comparison of thermal storage concepts. Value analyses are being performed to establish cost goals for thermal storage. The objective of the comparison is to identify promising thermal concepts for development based on the cost of delivered energy from the thermal storage-coupled solar thermal plant.

The comparisons are being conducted in a phased manner, as illustrated below:

- Phase 1. Preliminary Data

SERI in-house analyses of cost and performance of thermal storage concepts for:

(a) Water/Steam Central Receivers (Electric Power Application)

(b) Organic Fluid Receivers (Total Energy Application)

These data are documented herein.

- Phase 2. Decision Data

Stearns-Roger (a SERI subcontractor) will generate cost and performance data for thermal storage concepts for the following solar thermal receiver systems and their applications:

(a) Water/Steam Receiver

- Electric Power

- Process Heat

(b) Organic Fluid Receiver

- Total Energy

- Process Heat

(c) Gas-Cooled Receiver

- Electric Power

Based upon Stearns-Roger data, SERI will rank the concepts and make specific recommendations for research and development.

- Phase 3. Thermal Storage for Other Types of Solar Thermal Systems

The above steps are systematically repeated for all solar thermal systems/applications in the program plan. 
This report documents the results of the preliminary data from the first phase. The objectives of this study were:

- To provide thermal storage subsystem cost and performance data determined in a consistent manner for several types of thermal storage concepts; and to determine the impact of those concepts on solar thermal system cost;

- To obtain feedback information on the thermal storage concepts integrated into solar thermal systems;

- To recommend areas for research; and

- To provide SERI with sufficient experience to intelligently direct the more extensive effort of Stearns-Roger.

Readers are cautioned to consider the rather limited objectives of this report and to avoid generalizing from its results (i.e., do not extend the results for electric power to process heat; that case has not been examined). The data are intended to be generic (i.e., the analyzed concepts are representative of similar types). Many other concepts exist; the results of these analyses apply to those other concepts only to the extent that there is similarity to one of the concepts studied. In addition, the data presented herein are based on a limited, preliminary study, and a more in-depth study (Stearns-Roger) has been initiated at the time of this writing. Promising concepts for development will be identified based in part upon the latter data, which will be available in approximately one year. In the interim, the authors welcome suggestions for changes in the system configurations that could significantly improve the results.

The authors thank Lee Radosevich of Sandia Laboratories, Livermore; Cliff Schafer, also of Sandia Laboratories, Livermore; Jim Calogeras of NASA-Lewis Research Center; and Charles Wyman of SERI for their review of the results. Special thanks go to Joe Lavender of SERI who provided much of the basic cost algorithm data.

Approved for:

SOLAR ENERGY RESEARCH INSTITUTE

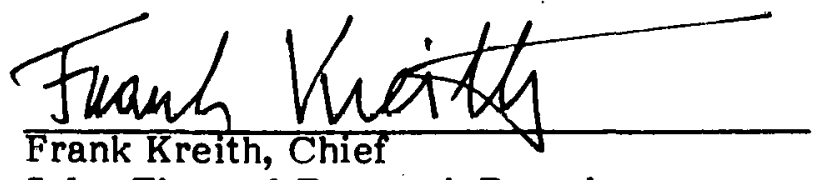

Solar Thermal Researah_Branch

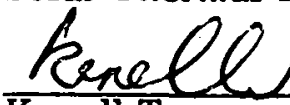

Kenell Touryan, Manage

Solar Thermal, Oceap and Wind Division

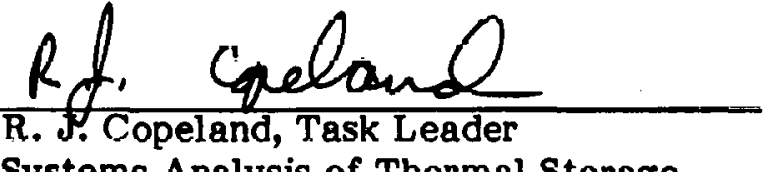
Systems Analysis of Thermal Storage

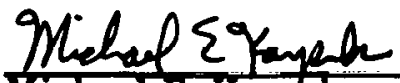
Michael E. Kartijk Systems Analyst

Qane Ullinax Jane Ullman

Systems Analyst 


\section{SUMMARY}

The DOE Divisions of Central Solar Technology (CST) and Energy Storage Systems (STOR) have developed a joint program plan to accelerate the development of thermal storage for solar applications. The plan focuses the development of thermal storage on six solar thermal collector/receiver systems and specific applications of each system. SERI supports this program by providing systems analysis. This report documents the SERI systems analysis of several thermal storage concepts for water/steam receiver and organic fluid receiver systems. The object of this study was to compare alternate thermal storage concepts for both collector/receiver systems in electric power and cogeneration applications, respectively.

A baseline solar thermal system design was selected for both applications. The McDonnell Douglas design of a $100-\mathrm{MW}$ plant (Barstow scale-up) was selected as representative of water/steam receiver systems. The General Electric designed Solar Total Energy Large-Scale Experiment at Shenandoah, Georgia, was selected as representative of organic fluid receivers. Detailed design information is available for both of these systems. Both designs included a storage system; a dual-media oil/rock thermocline system for the water/steam plant and a trickle charge oil/taconite system for the organic fluid receiver system.

Several alternate storage systems were designed for each of the baseline systems. The alternate systems were required to accept the charging and discharging fluid at the same rate as the baseline storage systems. The alternate storage system designs included molten salt, dual-media molten salt, two-stage salt, and phase change salt concepts. A total of seven alternate storage systems were designed for the water/steam receiver system and five for the organic fluid receiver system. If an alternate storage system provided steam at a higher (or lower) temperature and/or pressure, the increased (or decreased) plant electrical output was calculated.

Costs for the baseline and alternate thermal storage systems were calculated with a consistent set of cost algorithms; e.g., all of the storage tank costs were calculated with the same equation. Performance was similarly analyzed (e.g., the same pinch point temperature differences).

The alternate thermal storage systems were compared to the baseline thermal storage system based on changes in the cost of energy delivered from the solar plant. The change in the cost of the energy produced by the baseline plant with a baseline storage system was calculated for each alternate storage system. The analysis accounts for the differences in thermal storage system costs and first and second'law efficiencies due to the alternate storage system.

For the water/steam receiver application, a dual-media molten salt storage system produced the lowest energy cost for buffer storage. For diurnal storage, a two-stage system (dual media oil/rock low-temperature stage and a dual-media molten salt/ low-cost media high-temperature stage) produced the lowest energy cost. Both of the above, however, were only marginally lower than the baseline dual-media oil/rock. Phase change concepts require technical breakthroughs beyond the identified approach before they will be economically attractive.

For the organic fluid receiver application, a lower energy cost was obtained by replacing the taconite in the baseline system with a low-cost medium. Such a medium could be 
waste glass. Salt concepts were found to be competitive with the oil/taconite trickle charge concept only if the application requires a very large quantity of storage. As with the water/steam receiver application, the phase change concept studied was not competitive economically with the sensible heat concepts.

Several general conclusions and recommendations are drawn from the study. The baseline dual-media oil/rock and tricle charge oil/taconite systems are very good, and their further development is recommended. The alternate systems that are economically competitive require the use of a low-cost medium compatible with the working fluid (molten salt or Syltherm). Research to find such media is recommended. The phase change concepts, though not economically competitive in the systems studied, offer significant potential increases in efficiency for water/steam systems. Research in phase change systems are recommended to solve the identified cost problems. 


\section{TABLE OF CONTENTS}

1.0 Introduction $\ldots \ldots \ldots \ldots \ldots \ldots \ldots \ldots \ldots \ldots \ldots \ldots \ldots \ldots \ldots \ldots \ldots \ldots \ldots \ldots \ldots$

1.1 Thermal Storage Technology and Development Plan .............. 1

1.1.1. Objective of the Program Plan ....................... 1

1.1.2 Program Elements............................. 2

1.1.3 Role of SERI Systems Analysis ..................... 2

1.2 Objective of the Preliminary Screening ..................... 3

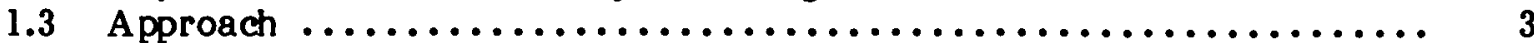

1.3.1 Generic Thermal Storage Concepts ................... 4

1.3.2 SERI Modifications to Concepts ................... 5

1.3.3 Criteria for the Preliminary Screening $\ldots \ldots \ldots \ldots \ldots \ldots \ldots \ldots \ldots$

1.3.4 Reference Systems ............................. 5

2.0 Concept Descriptions $\ldots \ldots \ldots \ldots \ldots \ldots \ldots \ldots \ldots \ldots \ldots \ldots \ldots \ldots \ldots \ldots \ldots \ldots \ldots \ldots$

2.1 Thermal Storage Systems for Water/Steam Central Receiver

Plants ....................................... 7

2.1.1 Oil/Rock Storage - Reference System ................ 9

2.1 .2 Draw Salt Storage ............................... 10

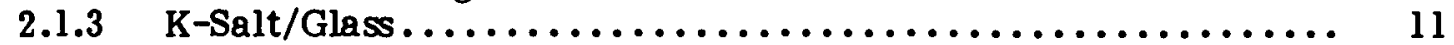

2.1.4 Two-Stage Salt Storage ....................... 12

2.1.5 Two-Stage Salt/Glass Storage .................... 12

2.1.6 Draw Salt/Glass and Oil/Rock Storage ................. 13

2.1.7 Phase Change Storage ........................ 14

2.1 .8 Improved Phase Change Storage .................... 16

2.2 Organic Fluid Receivers........................... 17

2.2.1 Shenandoah Reference System ................... 19

2.2.2 Trickle Charge Oil/Glass $\ldots \ldots \ldots \ldots \ldots \ldots \ldots \ldots \ldots \ldots \ldots \ldots \ldots \ldots, 19$

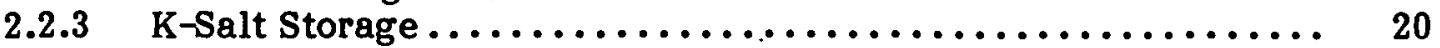

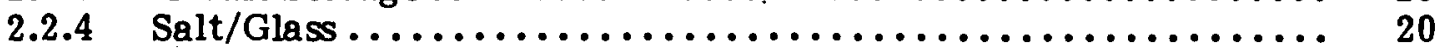

2.2.5 Phase Change Storage $\ldots \ldots \ldots \ldots \ldots \ldots \ldots \ldots \ldots \ldots \ldots \ldots \ldots \ldots \ldots \ldots$

3.0 Thermal Storage Subsystem Cost and Performance................ 23

3.1 Water/Steam Receiver Cost and Performance ................ 26

$3.1 .1 \quad$ Oil/Rock Storage.............................. 26

3.1 .2 Draw Salt Storage ........................... 26

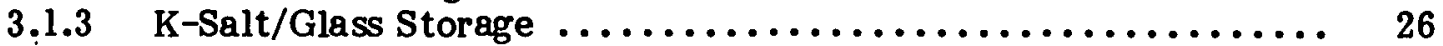

3.1 .4 Two-Stage Salt Storage ......................... 26

3.1.5 Two-Stage Salt/Glass Storage ..................... 27

3.1.6 Draw Salt/Glass and Oil/Rock Storage .................. 27

3.1.7 Phase Change Storage .......................... 27

3.1.8 Improved Phase Change ....................... 27

3.2 Cost and Performance of Thermal Storage for Organic Fluid

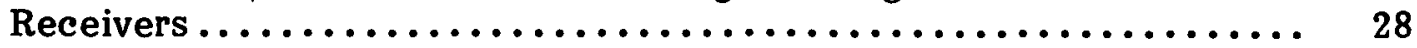

3.2.1 Shenandoah Reference System $\ldots \ldots \ldots \ldots \ldots \ldots \ldots \ldots \ldots \ldots \ldots . \ldots \ldots$

3.2 .2 Oil/Glass Trickle Charge $\ldots \ldots \ldots \ldots \ldots \ldots \ldots \ldots \ldots \ldots \ldots \ldots \ldots \ldots 28$ 


\section{TABLE OP CONTENTS (continued)}

$\underline{\text { Page }}$

$3.2 .3 \quad \mathrm{~K}$-Salt Storage $\ldots \ldots \ldots \ldots \ldots \ldots \ldots \ldots \ldots \ldots \ldots \ldots \ldots \ldots \ldots, 28$

3.2.4 Salt/Low-Cost Media Storage ..................... 28

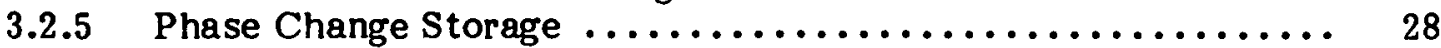

4.0 Ranking of Thermal Storage Concepts...................... 29

4.1 The Ranking Index.............................. 29

4.2 Results fur Water/Steam Collector/Receiver................ 30

4.2.1 Cost Data for Water/Steam ...................... 30

4.2.2 Per furmunce Dätä füi Water/3team ................ 90

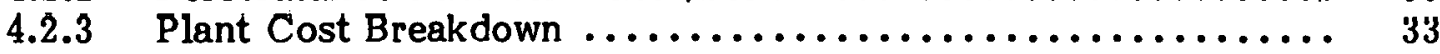

4.2.4 Appropriate Storage and Collector Area Combination ........ 34

4.2.5 Comparison of Concepts ........................ 34

4.3 Results of Organic Fluid Collector/Receiver ................ 40

4.3 .1 Cost Data for Organic Fluid ...................... 40

4.3.2 Performance Data for Organic Fluid ................. 40

$4.3 .3 \quad$ Plant Cost Breakdown ......................... 41

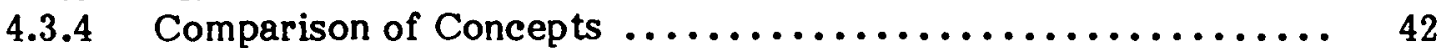

5.0 Conclusions and Recommendations $\ldots \ldots \ldots \ldots \ldots \ldots \ldots \ldots \ldots \ldots \ldots \ldots \ldots$

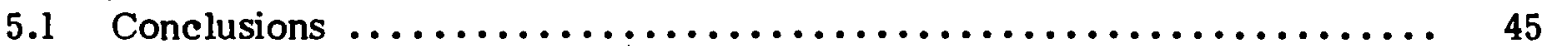

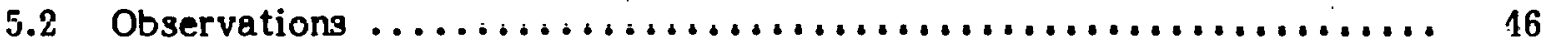

5.3 Recommendations .............................. 47

6.0 References $\ldots \ldots \ldots \ldots \ldots \ldots \ldots \ldots \ldots \ldots \ldots \ldots \ldots \ldots \ldots \ldots \ldots \ldots \ldots \ldots \ldots \ldots$ 


\section{UST OF FIGURES}

Page

1-1 Major Concept Comparison Milestones ...................... 3

1-2 Approach to the Comparison of Thermal Storage Concepts ............ 6

2-1 Artist's Conception of 10-MW Barstow Plant .................. 7

2-2 Schematic Diagram of 10-MW Central Receiver Power Plant .......... 8

2-3. Oil/Rock Thermal Storage System $\ldots \ldots \ldots \ldots \ldots \ldots \ldots \ldots \ldots \ldots \ldots \ldots \ldots \ldots . . \ldots$

2-4 Draw Salt Thermal Storage System $\ldots \ldots \ldots \ldots \ldots \ldots \ldots \ldots \ldots \ldots \ldots \ldots \ldots \ldots$

2-5 K-Salt/Glass Thermal Storage System $\ldots \ldots \ldots \ldots \ldots \ldots \ldots \ldots \ldots \ldots \ldots \ldots \ldots \ldots$

2-6 Two-Stage Salt System.............................. 12

2-7 Dual-Boiler Salt/Glass-Oil/Rock ......................... 13

2-8 Phase Change Salt Thermal Storage System, $99 \% \mathrm{NaNO}_{3}, 1 \% \mathrm{NaOH} \ldots \ldots . . . \quad 14$

2-9 Continuous Salt Flow Reflux Boiler $\ldots \ldots \ldots \ldots \ldots \ldots \ldots \ldots \ldots \ldots \ldots \ldots \ldots$

2-10 Improved Phase Change Concept $\ldots \ldots \ldots \ldots \ldots \ldots \ldots \ldots \ldots \ldots \ldots \ldots \ldots \ldots$

2-11 Artist's Concept of the Shenandoah Plant ..................... 17

2-12 Organic Fluid Receiver Reference System, Shenandoah Solar Total Energy System ................................... 18

2-13 Organic Fluid Receiver Reference Thermal Storage System ........... 19

2-14 Molten Salt Storage for Organic Fluid Receivers................. 20

2-15 Phase Change Storage for Shenandoah Total Energy System ........... 21

4-1 Cost Breakdown of Reference Water/Steam Collector/Receivers ......... 33

4-2 Comparison of Concepts at $0.5-\mathrm{km}^{2}$ Collector Area Low Storage Use ................................... 35

4-3 Comparison of Concepts at $1.0-\mathrm{km}^{2}$ Collec tór Area -

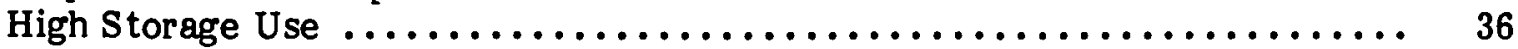

4-4 Comparison of Concepts at $1.5-\mathrm{km}^{2}$ Collector Area High Storage Use $\ldots \ldots \ldots \ldots \ldots \ldots \ldots \ldots \ldots \ldots \ldots \ldots \ldots \ldots \ldots \ldots \ldots \ldots$

4-5 Comparison of Concepts with $\pm 20 \%$ Variation in Thermal Storage

Subsystem Cost .................................. 39 
LIST OF FIGURES (continued)

Page

4-6 Cost Breakdown for Reference Organic Fluid Collector/Receiver

(For 192 Dishes, 10 Hours of Thermal Storage, Shenadoah

Technology)

4-7 Comparison of Thermal Storage Concepts - Shenandoah

Design: 192, 7-m Diameter Dishes - 10 Hours ..................... 43

4-8 Comparison of Concepts with $\pm 20 \%$ Variation in Thermal Storage

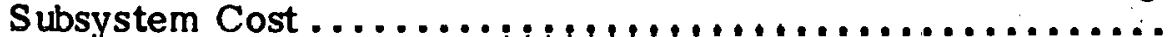


SEP

TR -647

LIST OF TABLES

Page

2-1 Properties and Cost of Thermal Storage Media

8

3-1 Comparison of Major Cost Elements of Thermal Storage Systems for Steam/Water Receivers

24

3-2 Comparison of Major Cost Elements of Thermal Storage Systems for Organic Fluid Receivers (6 Hours Storage)

25

4-1 Preliminary Cost Data for Storage with Water/Steam Receivers

31

4-2 Preliminary Performance Data for Concepts with Water/Steam ......... 32

4-3 Appropriate Area and Storage Capacity Combination............... 34

4-4 Performance Data for Concepts with Organic Fluid Receivers

41

$\mathrm{xi}$ 


\section{SECTION 1.0}

\section{INTRODUCTION}

Major considerations affecting the development of solar thermal power systems* for commercial use are: the need to provide continuous operation during periods of variable insolation and to extend operation into nonsolar hours; to buffer potentially harmful system transients induced by abrupt insolation changes; and to assure the availability of productive capacity during emergency periods. Two options exist for meeting these requirements: conventional backup systems and thermal storage.** Backup systems provide a viable near-term solution; however, as conventional fuel supplies become critically limited, due to cost or availability, thermal storage will assume an increasingly important role.

A comprehensive program has been drafted to facilitate the accelerated development of thermal energy storage technologies matched to solar thermal system requirements and scheduled milestones. The plan (U.S. DOE .1979) for this program was prepared at the joint request of the DOE Divisions of Central Solar Technology (CST) and Energy Storage Systems (STOR). The basic strategy of the program is both aggressive and flexible. Reflecting the current direction of the Thermal Power Systems (TPS) Branch of CST; storage for repowering/industrial retrofit, total energy, and small community system applications will be stressed in the early years.

\subsection{THERMAL STORAGE TECHNOLOGY DEVELOPMENT PLAN}

\subsubsection{Objective of the Program Plan}

The goals of the development program are to provide:

- Second-generation storage subsystems, offering cost performance improvements over the first-generation storage subsystems currently being developed for solar thermal power applications;

- First-generation storage subsystems for those solar thermal applications that presently have no storage subsystems; and

- A technology base to support storage subsystem development for future solar thermal power applications (third generation).

*Solar thermal power systems collect and concentrate the sun's radiant energy to heat a working fluid; i.e., convert the radiant energy to thermal energy. The thermal energy can be used directly for heat applications (process heat, heating, cooling, etc.) or to drive a heat engine, producing mechanical and/or electrical energy. Applications for the latter include, but are not limited to, electric utility power plants, irrigation pumping systems, and total energy systems (cogeneration).

**Backup systems include utility grids, fossil-fueled systems, batteries, pumped hydro, etc. Thermal storage includes sensible heat, latent heat, and thermochemical concepts. 


\subsubsection{Program Elements}

Seven elements have been defined in the storage development program. Six of the elements are keved to storage development for specific collector/receiver technologies; the seventh element is advanced thermal storage technologies. The elements are:

(1) Storage for water/steam-cooled collector/receiver.

(2) Storage for molten salt-cooled sensible heat collector/receiver.

(3) Storage for liquid metal-cooled sensible heat collector/receiver.

(4) Storage for gas-cooled sensible heat collector/receiver.

(5) Storage for organic fluid-cooled sensible heat collector/receiver.

(6) Storage for liquid metal/salt-cooled latent heat collector/receiver.

(7) Advaneed storage technologies (third generation).

Project applications* for the first six elements have been identified, providing a focus for the storage technology development.

\subsubsection{Role of SERI Systems Analysis}

SERI is supporting the joint CST-STOR program plan with systems analysis. This activity includes both value analysis and comparisons of thermal storage technologies.

The value of thermal. storage in a solar thermal system/application is a measure of its worth, or benefit, to the user. This benefit is measured by the cost of conventional fuel and equipment that is saved when thermal storage is used. Clearly, if the cost of a thermal storage system exceeds its value, a user would be expected to avoid the thermal storage in favor of a fossil-fueled backup. Program cost goals are always set equal to or less than that value. This procedure assures that only those technologies that have the potential of meeting (or surpassing) the cost goals will be developed, and furthermore, that they will be marketable.

Several thermal storage technologies are expected to meet the value-derived cost goals. Program resources are limited, and only a few thermal storage concepts can be developed. Obviously, these should be only those that are most promising technically and economically. SERI is supporting the selection process by reviewing data being generated by the developers of each technology and comparing the technologies on an equal basis. These comparisons are conducted in accordance with the program elements, identifying thermal storage technologies appropriate to each of the solar thermal systems.

\footnotetext{
*The repowering/industrial retrofit program may result in two system applications: repowering of an existing electric power generating plant and retrofitting of an existing industrial process heat plant. Storage reauirements, which may differ significantly for the two applications, will be further refined pending completion of conceptual design studies in FY80.
} 


\subsection{OBJECTIVE OF THE PRELIMINARY SCREENING}

The objective of SERTs comparison effort is to identify thermal storage concepts with the potential of a significant reduction in the cost of the storage-coupled solar thermal system. According to the latest version of the Thermal Energy Storage for Solar Thermal Applications Multiyear Program Plan, the goal is to reduce the cost of the thermal storage subsystem by $24 \%$ to $57 \%$ below the first-generation cost while simultaneously improving the round-trip efficiency of the thermal storage. Clearly, the program goals are to make technological breakthroughs. SERIs comparison effort is being conducted to identify where those breakthroughs can come.

The preliminary screening study is being conducted by SERI personnel. The objectives have been limited to providing some early guidance to the program managers and other interested parties, to providing a basis for information exchange (i.e., better descriptions of the concepts), and to providing SERI with sufficient background to properly monitor a later, in-depth study. To meet these objectives, an examination of the cost and performance of thermal storage concepts for water/steam collector/receiver and organic fluid collector/receiver systems was conducted, and this report documents its results.

Figure 1-1 presents the major milestones in the Thermal Storage Program Plan that SERI is supporting. The milestone for the preliminary screening is this report. The first decision points on specific technologies will be reached in about one year from this writing. Cost and performance data for those decision points will be generated by a SERI subcontractor who is experienced in the design and costing of commercial hardware.

Fiscal Year

\begin{tabular}{|c|c|c|c|c|}
\hline \multirow{2}{*}{ Activities } & 79 & 80 & 81 & 82 \\
\hline & & & & \\
\hline \multicolumn{5}{|l|}{ Preliminary Screening - } \\
\hline \multirow{4}{*}{$\begin{array}{l}\text { Decision Data on } \\
\text { Collector/Receivers } \\
\text { - Water/Steam - } \\
\text { - Liquid Metal } \\
\text { - Gas Cooled - } \\
\text { - Organic Fluid - }\end{array}$} & & & $\nabla$ & \\
\hline & & & & $\nabla$ \\
\hline & & & $\nabla$ & \\
\hline & & & & \\
\hline & & & & \\
\hline
\end{tabular}

Figure 1-1. Major Concept Comparison Milestones

\subsection{APPROACH}

The approach to the preliminary screening study is to cover the entire range of systems and concepts. Both large and small solar thermal systems are considered, as well as 
in

electric power, process heat, and total energy applications. In addition, a wide range of second-generation thermal storage concepts are also considered. This study addresses thermal storage concepts for the following two cases:

I. Water/Steam Collector/Receiver
(a) Large Power, $100 \mathrm{MW}$.
(b) Electric Power Application
(c) Barstow Technology Solar Thermal Plant

II. Organic Fluid Collector/Receiver

(a) Small Power, $2944 \mathrm{~kW}$ (10 MBtu/h)

(b) Total Energy Application with Electric Power, Process Heat, and LowTemperature Heat for Heating and Cooling

(c) Shenandoah Technology Solar Thermal Plant

These two cases are directly related to the first decision points. The solar thermal collector/receiver technology reference systems are also the systems currently planned for large-scale project applications of the second-generation thermal storage technologies.

\subsubsection{Generic Thermal Storage Coneepts}

Second-generation sensible and latent heat thermal storage technologies were studied generically. Thermochemical systems were excluded, as they were considered to be third-generation (advanced) concepts. Sensible heat concepts include single-stage and two-stage concepts, and both may be configured with or without dual media. Although latent heat concepts employ a phase change, they also can be combined with sensible heat storage concepts.

The approach was to study specific thermal storage concepts as representative of classes of technologies. The classes considered are as follows:

\begin{tabular}{lll}
\hline $\begin{array}{c}\text { Class of Thermal } \\
\text { Storage Technology }\end{array}$ & \multicolumn{1}{c}{$\begin{array}{c}\text { CONCEPTS STUDIED } \\
\text { Water/Steam } \\
\text { Collector/Receiver }\end{array}$} & $\begin{array}{c}\text { CASE II } \\
\text { Orgario Fluid } \\
\text { Collector/Receiver }\end{array}$ \\
\hline Sensible: & Oil (Caloria)/Rock & Syltherm/Taconite \\
Organic & $\begin{array}{c}\text { Salt } \\
\text { Dual-Media }\end{array}$ & $\begin{array}{l}\text { Salt } \\
\text { Dual-Media Salt }\end{array}$ \\
Inorganic & Salt and Oil/Rock & None \\
Two-Stage & $\begin{array}{c}\text { Two Types of Salts } \\
\text { and Dual-Media Salts }\end{array}$ & \\
\hline Latent Heat & Salt Phase Change & Salt Phase Change
\end{tabular}

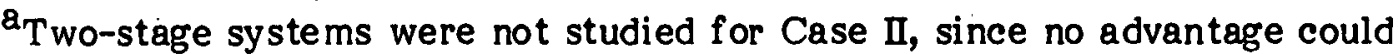
readily be identified. 
This approach has the obvious advantage of covering a large range of concepts with a minimum of effort. The disadvantage is that there may be concepts in a class (other than the one studied) that are significantly better. The authors recognize this problem and have attempted to employ the best concept definition available. Many other concepts do exist. Including various versions of the specific ones studied, more optimal designs may exist. Based on analyses conducted as part of this study, optimizing has a small effect (approximately $3 \%$ of the thermal storage subsystem cost). However, the program is seeking concepts with $20 \%$ to $30 \%$ and higher improvements in the thermal storage. Since the optimizing effect is small compared to the improvements being sought, the generic approach was adopted for this study.

\subsubsection{SERI Modifications to Concepts}

The specific concepts examined in this study are those that are currently being developed or are a minimal modification of such. Whenever possible, data from the developer of a concept is employed. Many modifications were made by SERI to either improve or add necessary technical features. For example, analyses were conducted with low-cost solid media (for example, recycled glass) in molten salts as well as single-medium molten salt storage. Also, the phase change concept, as described by the developer, was modified to include a superheat capability (during discharge) as well as the defined capacity to boil water. Modifications to concepts were in general relatively minor technical changes, and similar items are either currently being developed or have previously been demonstrated. The modifications, and indeed other similar improvements, could be developed within the time frame of the second-generation development schedules. In all cases, the modifications were made to achieve the best system configuration for each concept.

\subsubsection{Criteria for the Preliminary Screening}

Several factors must be considered when selecting concepts for development - including costs in commercial use, development costs, risks, environmental impacts, etc. The appropriate concept(s) to develop must eventually be acceptable in all areas. A first screening may be conducted on any one parameter. The goal of the thermal storage program is to provide a reduction in the delivered energy costs of an $n^{\text {th }}$ commercial plant. That criteria is employed to screen the concepts; at a later date, the other criteria will be applied to those concepts that meet the program goal.

\subsubsection{Reference Systems}

Thermal storage is not an energy source, but a means of modulating an energy supply to meet a demand. The cost associated with thermal storage includes both the cost of the storage hardware and costs incurred by the performance of the storage subsystem. To determine the latter, a solar thermal system must be defined. To perform the comparison fairly (i.e., to isolate the differences due to the thermal storage concepts), all storage concepts are examined using the same solar thermal collector/receiver system. That system is designated as the reference system, and it includes a reference thermal storage concept designated as $\mathrm{R}$.

Figure 1-2 illustrates the approach. A complete solar thermal system is chosen for the analysis, including the collector, power generation (if applicable), thermal storage, etc. 
Without changing the remainder of the subsystems, the reference thermal, storage concept, $R$, is removed and an al ternative concept, $A$, replaces $R$. All necessary changes are included, and the cost differentials (either up or down) are regarded as part of the cost of the alternative concept. This process is repeated, systematically varying the collector field size (with a proportional change in the tower/receiver system), dispatch strategy, location, and quantity of storage. The impact on the energy system cost is determined for each combination. This approach therefore identifies which conditions, if any, influence the choice of thermal storage concepts.

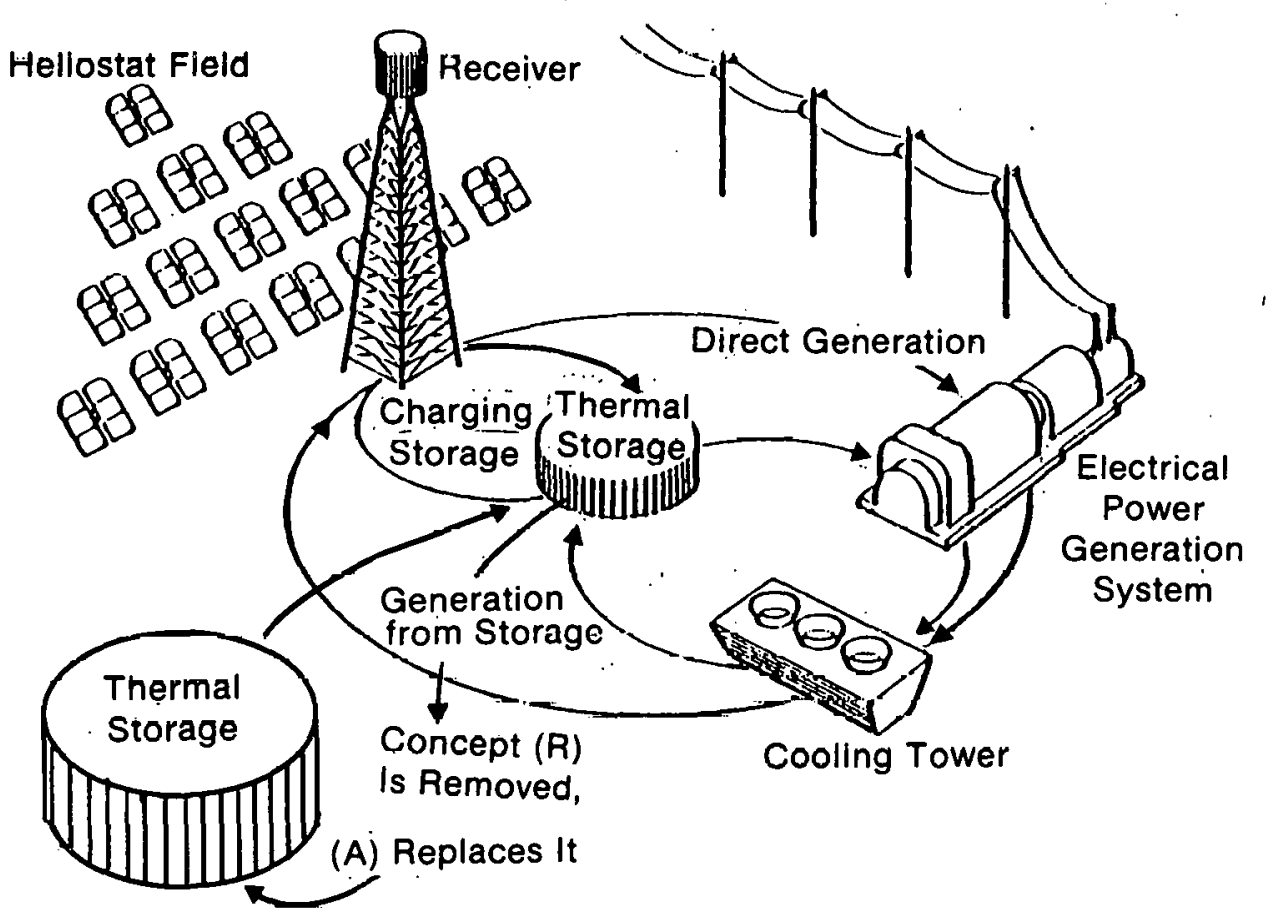

All other elements are unchanged (except as may be associated with the new storage, e.g., a đual adomiśsion turbine may be replaced with a single admission turbine if the storage allows it).

Figure 1-2. Approach to the Comparison of Thermal Storage Concepts

In Section 2.0, the reference collector/receiver systems and thermal storage concepts are described. Cost data and performance data are presented in Section 3.0 for each of the concepts studied. In Section 4.0, the methodology for ranking the concepts is described, and the cost comparisons are presented for varying missions of the storagecoupled solar thermal systems. Conclusions and recommendations are presented in Section 5.0. 
SECTION 2.0

\section{CONCEPT DESC.RIPTIONS}

\subsection{THERMAL STORAGE SYSTEMS FOR WATER/STEAM CENTRAL RECEIVER PLANTS}

The thermal storage svstems considered for water/steam receivers were designed to be compatible with a $100-\mathrm{MW}$ central receiver plant. This technology is being developed by MeDonnell Douglas Astronautics Company for the Barstow 10-MW application. Figure 2-1 is an artist's rendering of the plant design. The heliostats are mirrors reflecting the sunlight to a receiver at the top of the tower. Water is circulated to the receiver, where it is boiled, superheated, and returned to the base of the tower. The heat content of the steam is then either stored or is used directly to generate electricity in a steam power cycle. Figure 2-2 is a simplified schematic of the overall system (Hallet 1977), illustrating the relationship of the thermal storage unit to other plant components.

The storage system is charged at a flow rate of $727,000 \mathrm{lb} / \mathrm{h}$ with steam at $950^{\circ} \mathrm{F}$ and 1465 psia. The feedwater is coming into the storage system at a flow rate of $905,000 \mathrm{lb} / \mathrm{h}$ and is at $250^{\circ} \mathrm{F}$. These two sets of parameters are used as the basic design conditions to be met in making the storage subsystem compatible with the baseline plant design.

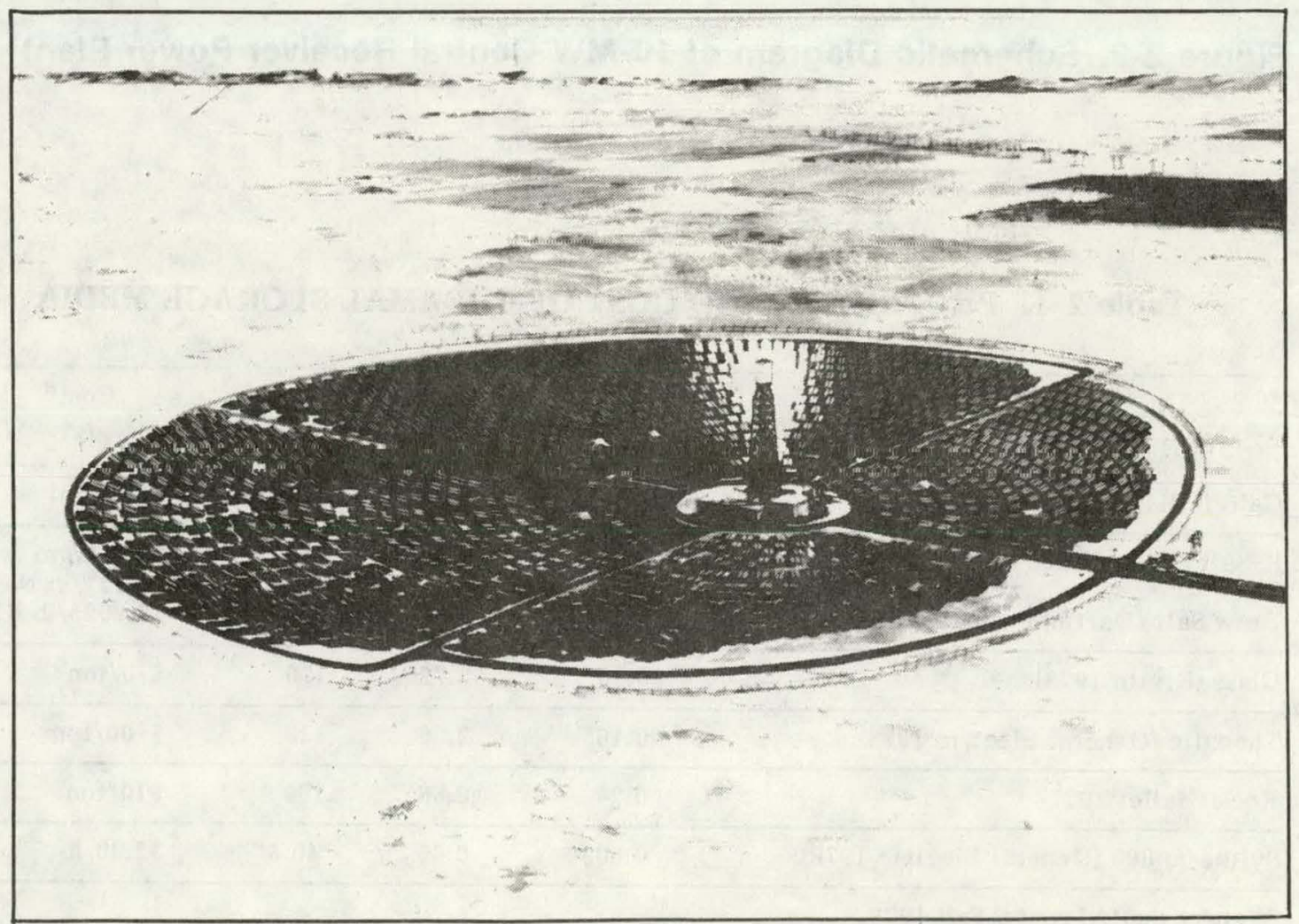

Figure 2-1. Artist's Conception of 10-MW Barstow Plant 


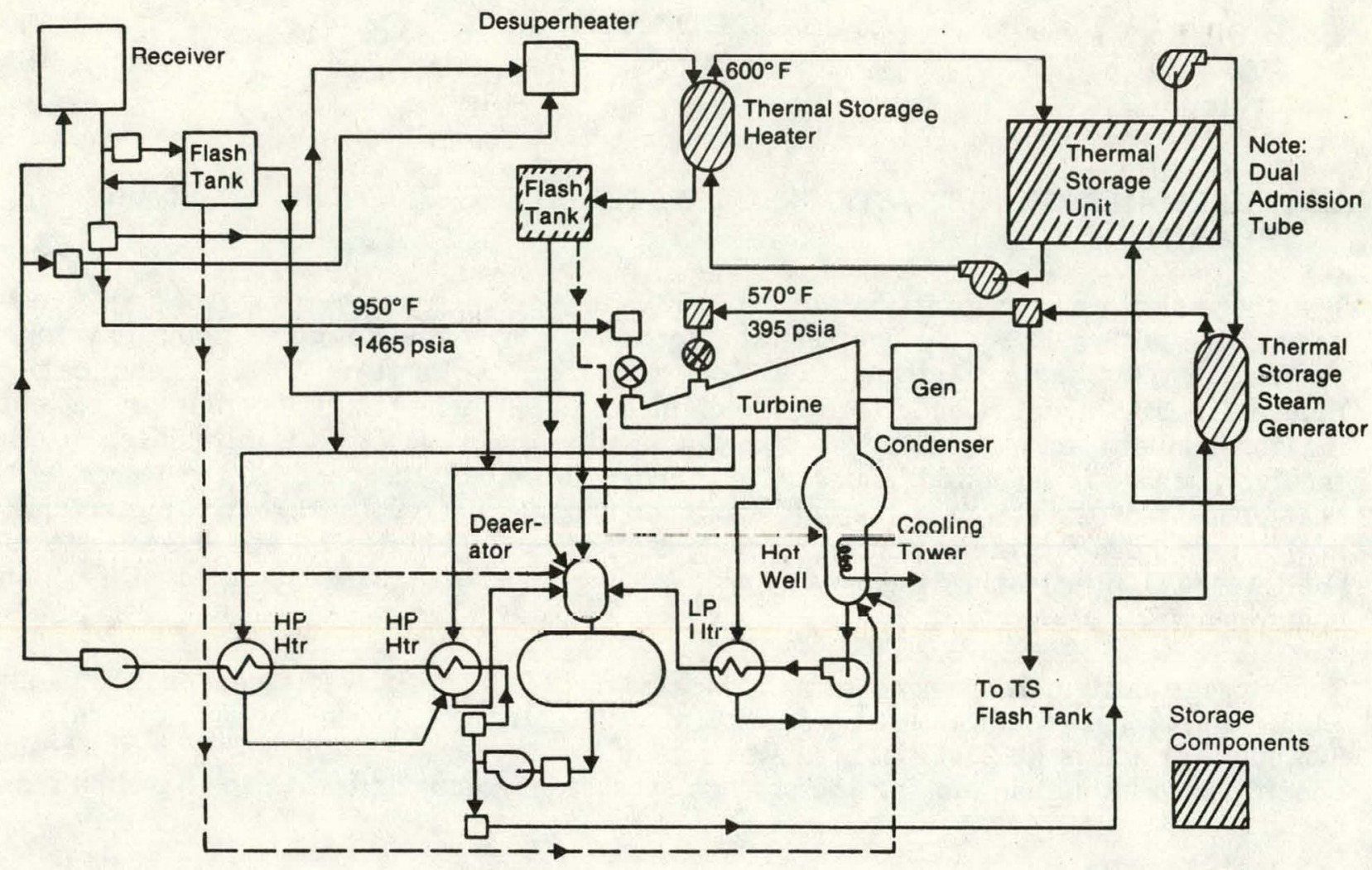

Figure 2-2. Schematic Diagram of 10-MW Central Receiver Power Plant

Table 2-1. PROPERTIES AND COST OF THERMAL STORAGE MEDIA

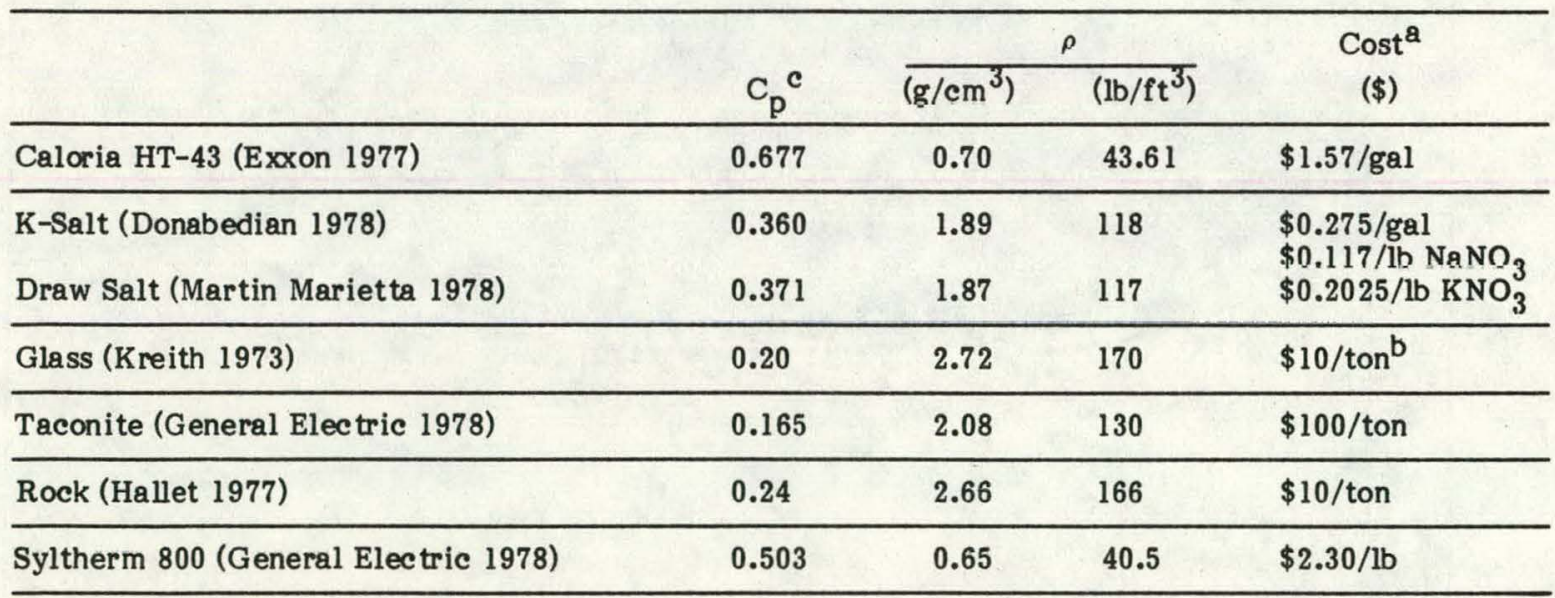

${ }^{a}$ Vendor quoted costs, Fall 1979.

bstimated as the same as rock for recycled glass.

${ }^{\mathrm{C}} \mathrm{Cal} / \mathrm{gm}-{ }^{\circ} \mathrm{C}$ and $\mathrm{Btu} / \mathrm{lb}-{ }^{\circ} \mathrm{F}$. 


\subsubsection{Oil/Rock Storage - Reference System}

The type of thermal storage system designed by McDonnell Douglas - dual-media, oil/rock thermocline - was used as the reference system for this portion of the study. A schematic of the oil/rock storage is shown in Fig. 2-3; the properties of the thermal storage media employed in this study are given in Table $2-1$.

In the reference oil/rock system, the oil is heated to $592^{\circ} \mathrm{F}$ by the central receiver steam and is then pumped into a single thermocline storage tank. The oil heats the rock, and both of the media are stored in the tank.

The capacity of the system is three hours of discharge. During discharge of the storage, the oil passes through a series of heat exchangers, heating the feedwater and converting it to $570^{\circ} \mathrm{F}, 395-p s i a$ superheated steam.

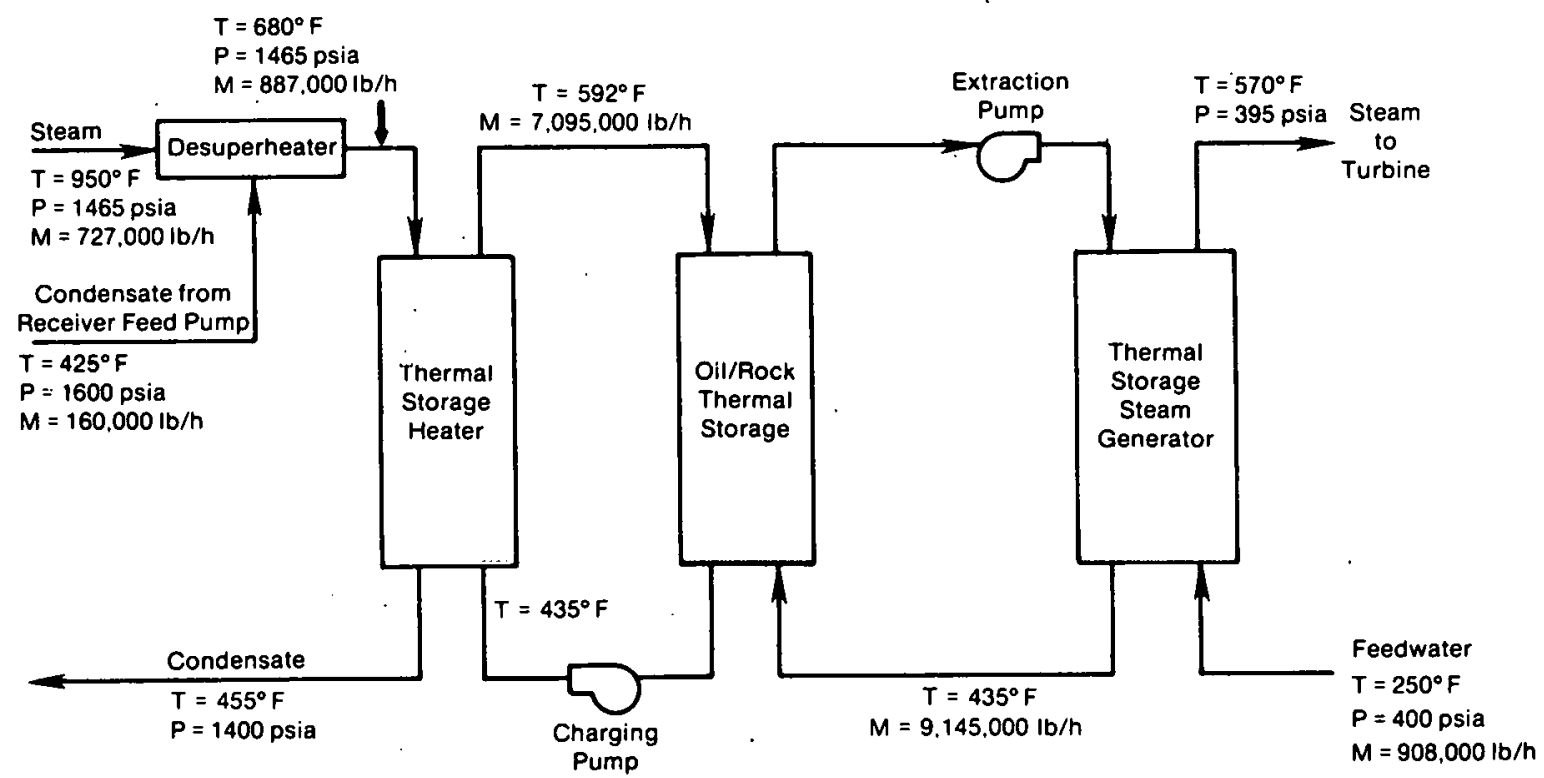

Figure 2-3. Oil/Rock Thermal Storage System 


\subsubsection{Draw Salt Storage}

Draw salt is being developed for molten salt receivers and has been shown to be of low cost in such use (Martin 1978). Draw salt, which is $40 \% \mathrm{KNO}_{3}$ and $60 \% \mathrm{NaNO}_{3}$ (by weight), was investigated as a thermal storage medium for the water/steam receiver plant. The storage concept in this system, as depicted in Fig. 2-4, is simply circulation of the salt to collect heat from receiver steam, and then storage of the salt in a single, externally insulated, plain carbon steel thermocline tank. The salt is capable of withstanding $1000^{\circ} \mathrm{F}$; however, due to pinch point problems, only $600^{\circ} \mathrm{F}$ can be obtained in a single-stage system.

The melting point of draw salt is $440^{\circ} \mathrm{F}$, which imposes restrictions on the discharge portion of the system. Since the plant feedwater enters at $250^{\circ} \mathrm{F}$, it must be preheated before entering the salt/water heat exchanger so that solidification of the salt on heat exchanger tubes is prevented. This constraint necessitates the addition of a feedwater heater to the system. The final exit conditions of the steam are $550^{\circ} \mathrm{F}$ and 500 psia. To avoid excess wetness in the lower stages of the turbine, the pressure is throttled to 400 psia before entering the turbine.

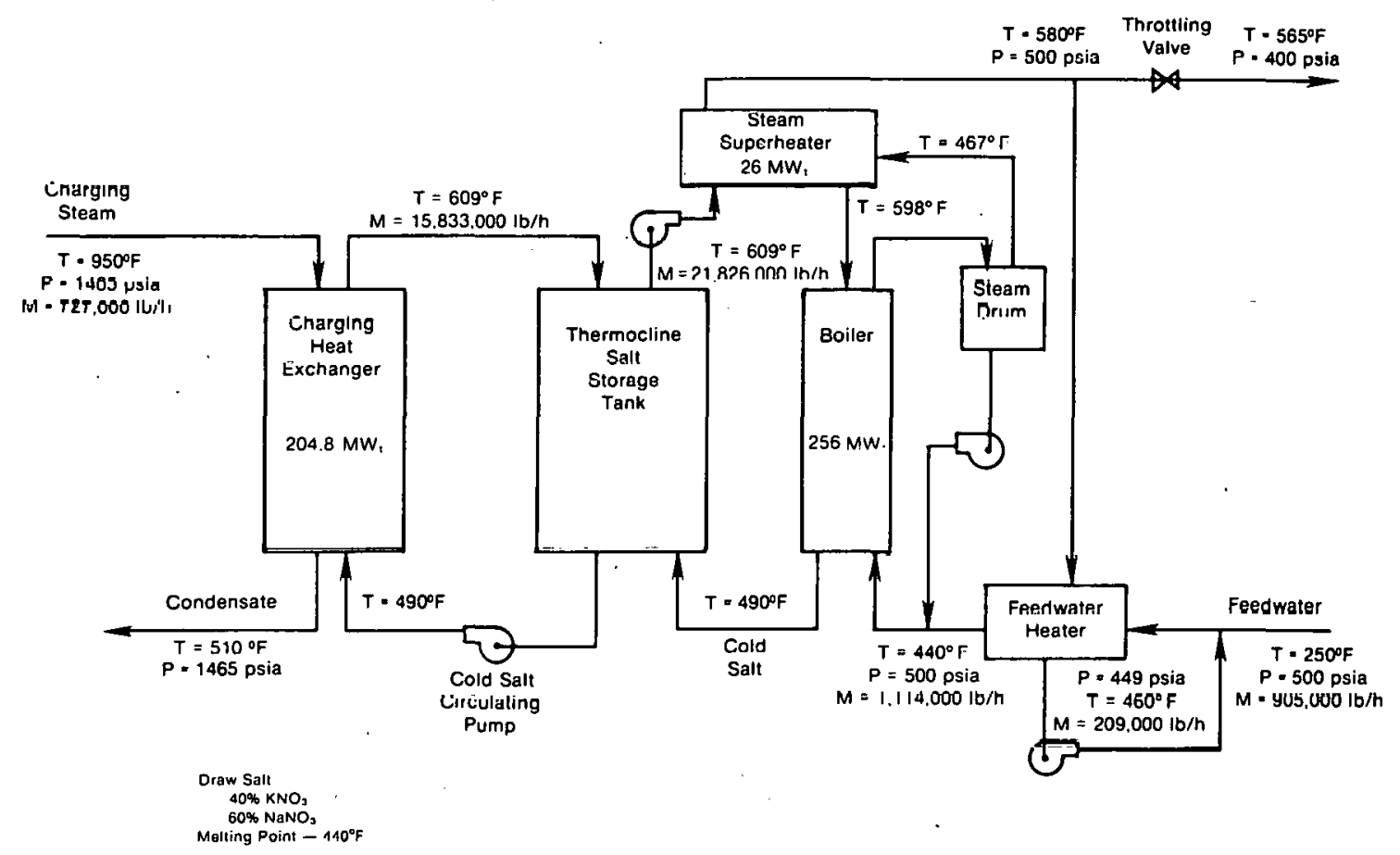

Figure 2-4. Draw Salt Thermal Storage System 


\subsubsection{K-Salt/Glass*}

Recognizing that draw salt, due to its comparatively high melting point, did not provide a large temperature differential in the storage tank, a lower melting point salt was considered. By using $50 \% \mathrm{NaNO}_{3}, 35 \% \mathrm{KNO}_{3}$, and $15 \% \mathrm{NaNO}_{2}$ (by weight), a salt with a melting point of $390^{\circ} \mathrm{F}$ is produced, allowing the same storage capacity to be met with $a$ smaller amount of medium. In addition to altering the salt composition, a low-cost, second medium was added to reduce overall system expense. The properties of recycled glass, see Table 2-1, were used in this analysis, but the general concept is simply to use any low-cost material that is compatible with the salt.

As with draw salt, a feedwater heater is required in this system, but the amount of preheating necessary is minimized, so the size of the preheater is decreased. The method of operation of this $\mathrm{K}-\mathrm{salt} / \mathrm{glass}$ system is similar to that of the draw salt (Fig. 2-5). The outlet temperature of the steam is approximately $600^{\circ} \mathrm{F}$, again restricted by pinch point limitations. Throttling is not required, because the water may be boiled at a lower temperature and pressure.

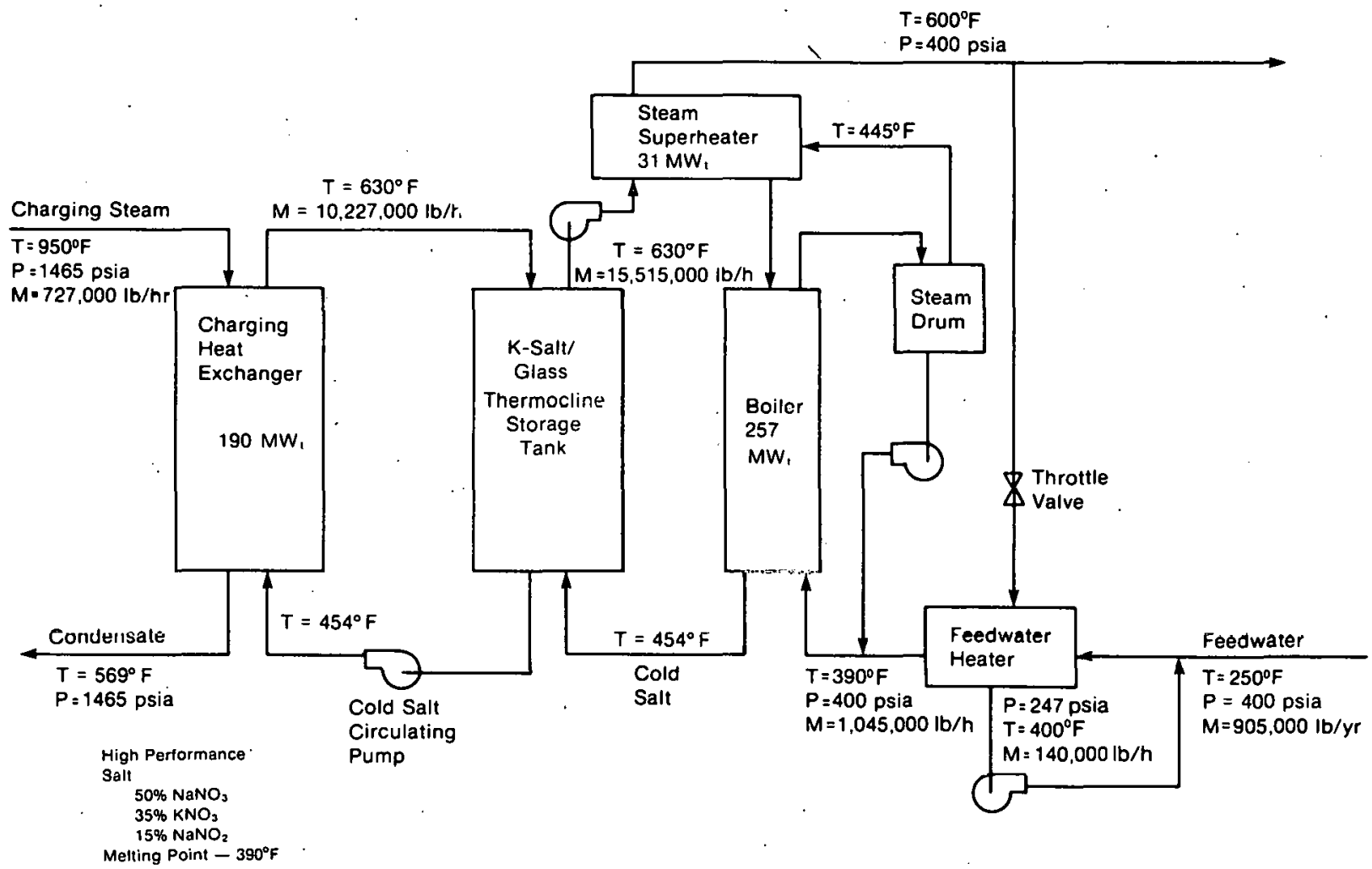

Figure 2-5. K-Salt - Glass Thermal Storage System

*This salt is similar to Hitec but has a lower concentration of the nitrite, reducing costs. 


\subsubsection{Two-Stage Salt Storage}

To make better use of the available temperatures in the steam and the high-temperature capability of the salt, two-stage salt systems have been proposed (Sandia 1977). Several versions of two-stage concepts were studied and are described in the following paragraphs.

Figure 2-6 presents a concept employing only molten salts. For the high-temperature portion of the cycle, draw salt is used; the heat stored in the draw salt supplies the energy for all of the steam superheating, and for part of the boiling. A low melting point salt stores the lower-temperature energy and does the preheating and the remainder of the boiling.

As with the other salt systems, a feedwater heater is required to adequately raise the entering water temperature. The size of this heat exchanger is, however, relatively small due to the high temperature of the steam drawn off the existing steam line. The exit steam, because of the improved system performance, is raised to $750^{\circ} \mathrm{F}$ and has a higher pressure, 150 psia.

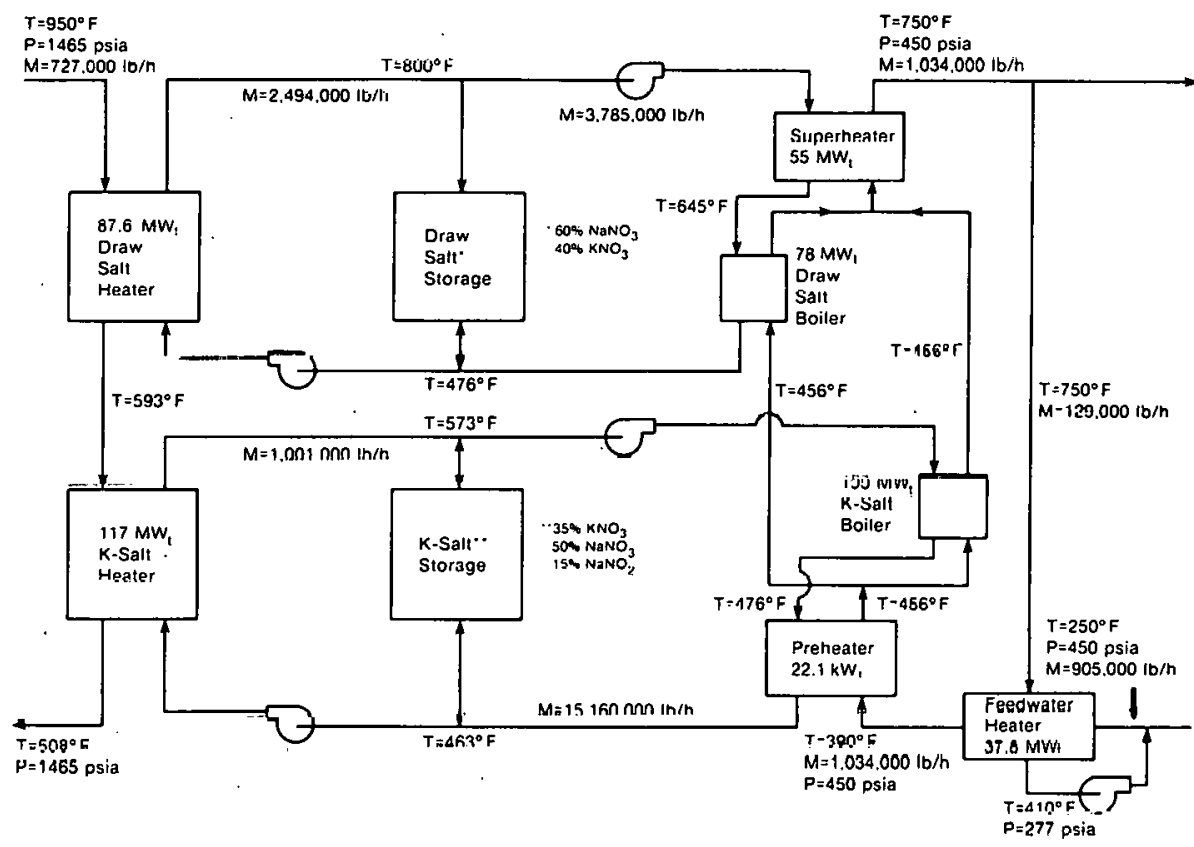

Figure 2-6. Two-Stage Salt System

\subsubsection{Two-Stage Salt/Glass Storage}

Although the two-stage salt system improves performance, it also incurs higher costs by requiring large amounts of expensive salts. To counteract this effect, a two-stage salt/ glass system was developed. The system operates in the same manner as the two-stage salt system shown in Fig. 2-6. This concept minimizes the use of salts by replacing much of the heat-storage capacity with a low-cost medium. Again, the properties of recycled glass were used to evaluate the system, although the intent is to use any appropriate, inexpensive material. System operation is analagous to that of the two-stage sa]t system, and the outlet steam conditions remains at $750^{\circ} \mathrm{F}, 450$ psia. 


\subsubsection{Draw Salt/Glass and Oil/Rock Storage}

Another concept considered was designed to incorporate the low-temperature capabilities of oil, the low cost of rock, and the high-temperature capabilities of salt into a twostage storage system. As Fig. 2-7 shows, the high-temperature storage is accomplished using a draw salt/low-cost solid medium (recycled glass) thermocline tank, and the lowtemperature storage is an oil/rock thermocline tank. In this way, the need for any feedwater preheating and the resulting cost are removed by using an oil transfer fluid. As with the two-stage salt/glass storage, the outlet temperature of the steam in the salt/glass and oil/rock system is $750^{\circ} \mathrm{F}, 450$ psia.

Two tank materials were considered for the high-temperature salt tank: stainless steel and plain carbon steel. Both tank materials are assumed to be externally insulated. The carbon steel is much less expensive but may not be acceptable at the conditions of storage; if not, the expensive stainless steel is the appropriate choice.

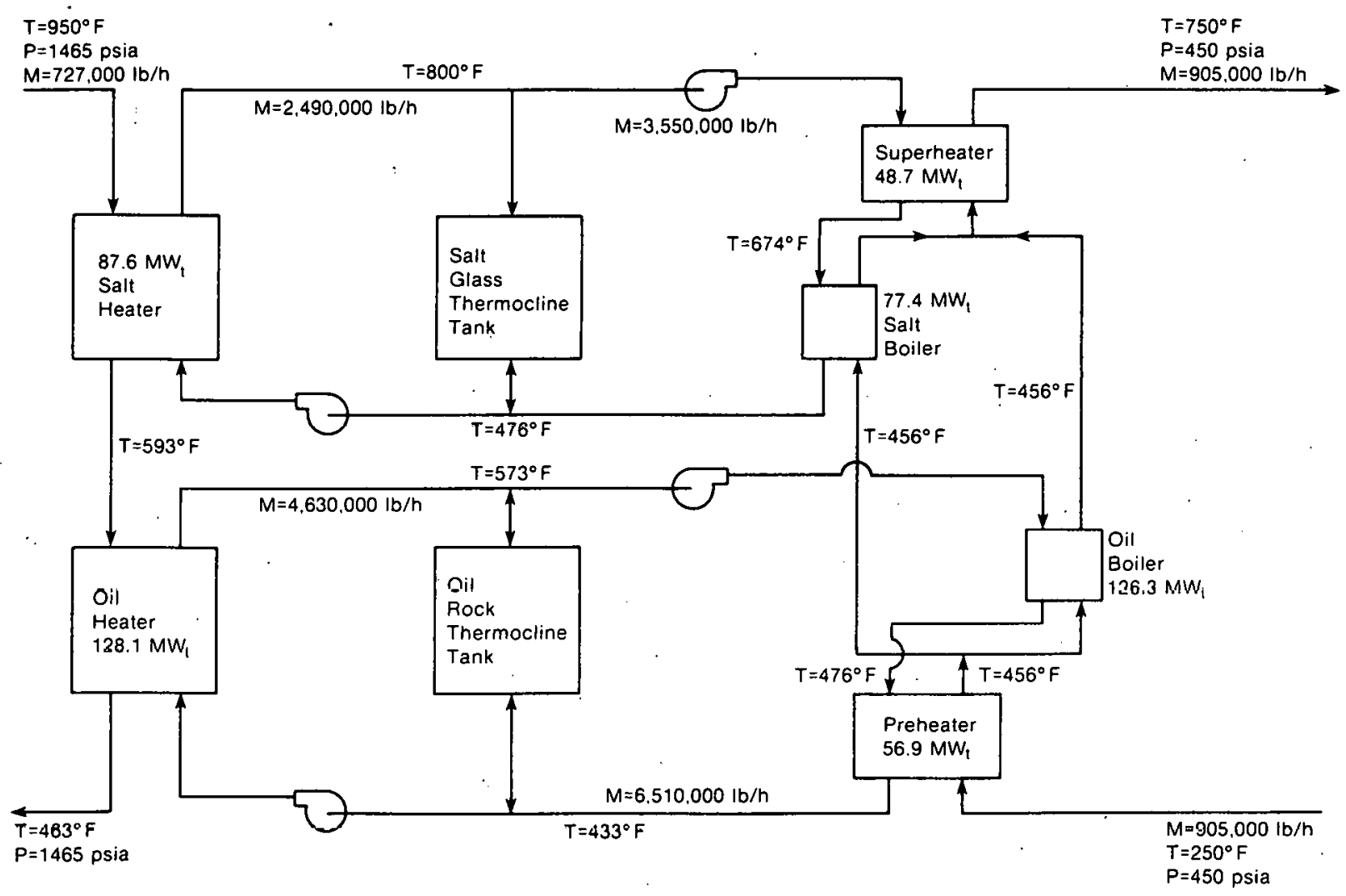

Figure 2-7. Dual Boiler Salt/Glass-Oil/Rock 


\subsubsection{Phase Change Storage}

The final generic concept considered for thermal storage in water/steam receiver plants was a phase change salt storage. This system, unlike the others, utilizes the latent heat storage capacity of a $99 \% \mathrm{NaNO}_{3}, 1 \% \mathrm{NaOH}$ salt. This concept is similar to that described by Lefrois et al. (1979), but modified to include a superheat capability and an active heat exchanger during charging.

The salt in slush form (60\% solids) can be pumped, and it is passed through a heat exchanger to melt during storage system charging (Fig. 2-8). Part of the resulting liquid is then superheated and stored to be used as the energy source for superheating the steam. Most of the liquid salt is returned to the slush storage tank. During discharge, liquid is pumped into the reflux boiler, which is shown in Fig. 2-9. Water comes into direct contact with the liquid salt at $585^{\circ} \mathrm{F}, 1600 \mathrm{psia}$, causing partial solidification of the salt and vaporization of the water. The steam produced then passes over the outside heut exchanger, where the system feedwater is bolled. (The intermediate loop, involving the reflux boiler, is required to prevent contamination of the power cycle feedwater with salt.) Stcam superheating is accomplisilıed in a separate heat exchanger. 'The outlet steam conditions are $850^{\circ} \mathrm{F}, 100$ psia. This concept requires charging steam at 1800 psia (versus the reference concept at 1465 psia). The costs associated with the higher pressure receiver were assumed to be small. The performance difference is accounted for in the analyses.

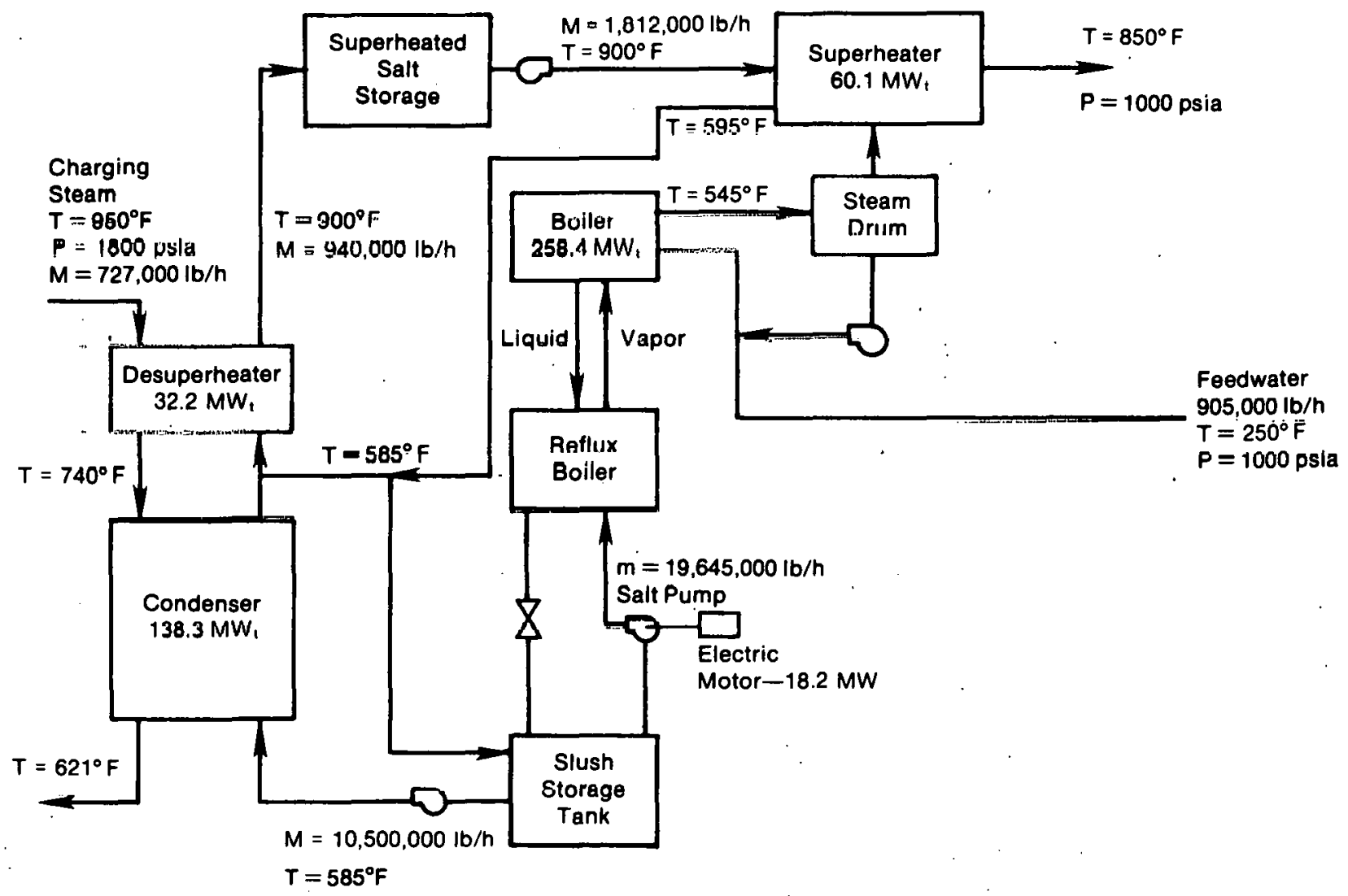

Figure 2-8. Phase Change Salt Thermal Storage System $99 \% \mathrm{NaNO}_{3}, 1 \% \mathrm{NaOH}$ 


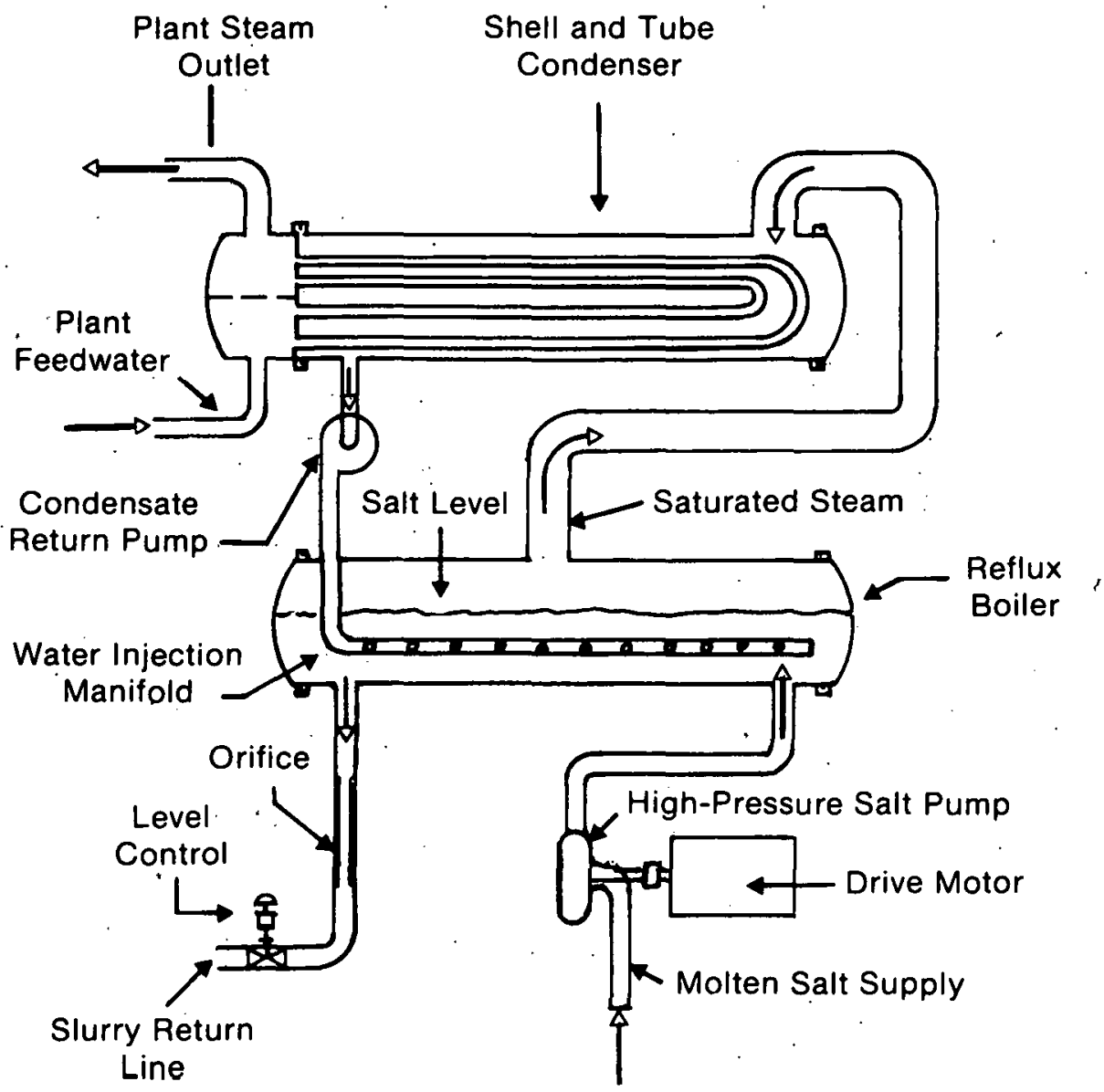

Figure 2-9. Continuous Salt Flow Reflux Boiler 


\subsubsection{Improved Phase Change Storage}

The major drawback of the phase change storage system described above is the parasitic power loss associated with the storage-to-reflux boiler salt pump. An improvement, suggested by Lefrois et al. (1979), is shown in Fig. 2-10; the pump moves 19,645,000 lb/h and raises the pressure to 1600 psia. Part of this energy may be recovered by placing a turbine between the reflux boiler and the slush storage tank. If such a turbine were developed (at $70 \%$ efficiency) approximately one-half of the power required to operate the salt pump could be recovered. SERI recognizes the risk in development of such a turbine. The purpose of including the concept in this analysis is to determine whether such a development would be worthwhile.

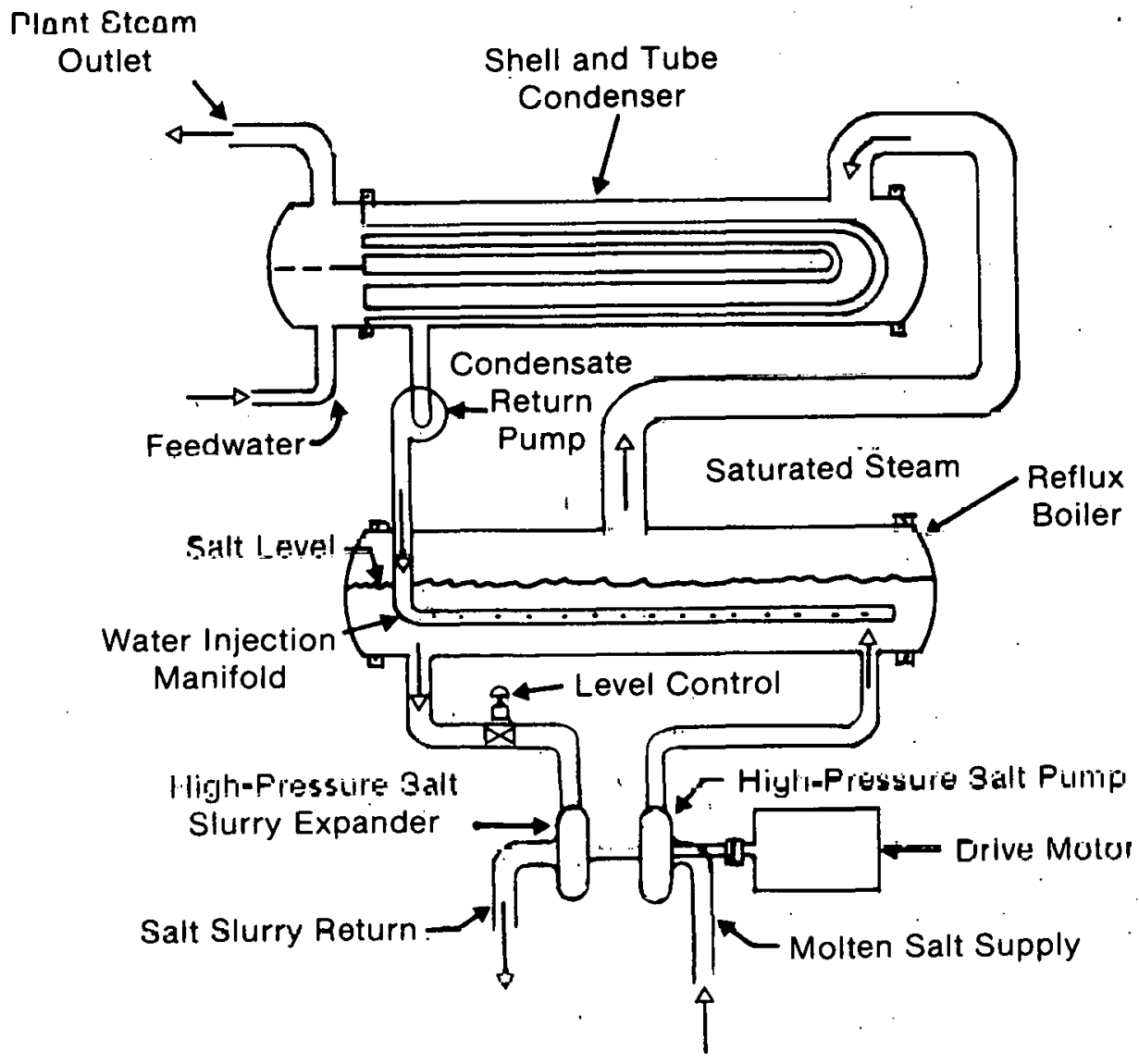

Figure 2-10. Honeywell - Pressure Recovery Turbine 


\subsection{ORGANIC FLUID RECEIVERS}

The Solar Total Energy Large-Scale Experiment at Shenandoah, Georgia, was selected as a reference system representative of a solar thermal system with organic fluid receivers. The solar collector field has 192 seven-meter diameter dish collectors. Dow Corning Syltherm 800 is the receiver heat transfer fluid. The collector field outlet temperature is $750^{\circ} \mathrm{F}$. An artist's conception of the plan is shown in Fig. 2-11 (General Electric Co. 1979).

The energy collected by the dishes is used to generate steam at 700 psig, $720^{\circ} \mathrm{F}$, in a 2944-kW boiler. Electricity is produced by expanding steam through a turbine to 110 psig. At this point, the steam may be diverted to direct process uses, or it can be further expanded to produce more electricity. A process diagram of the system is shown in Fig. 2-12.

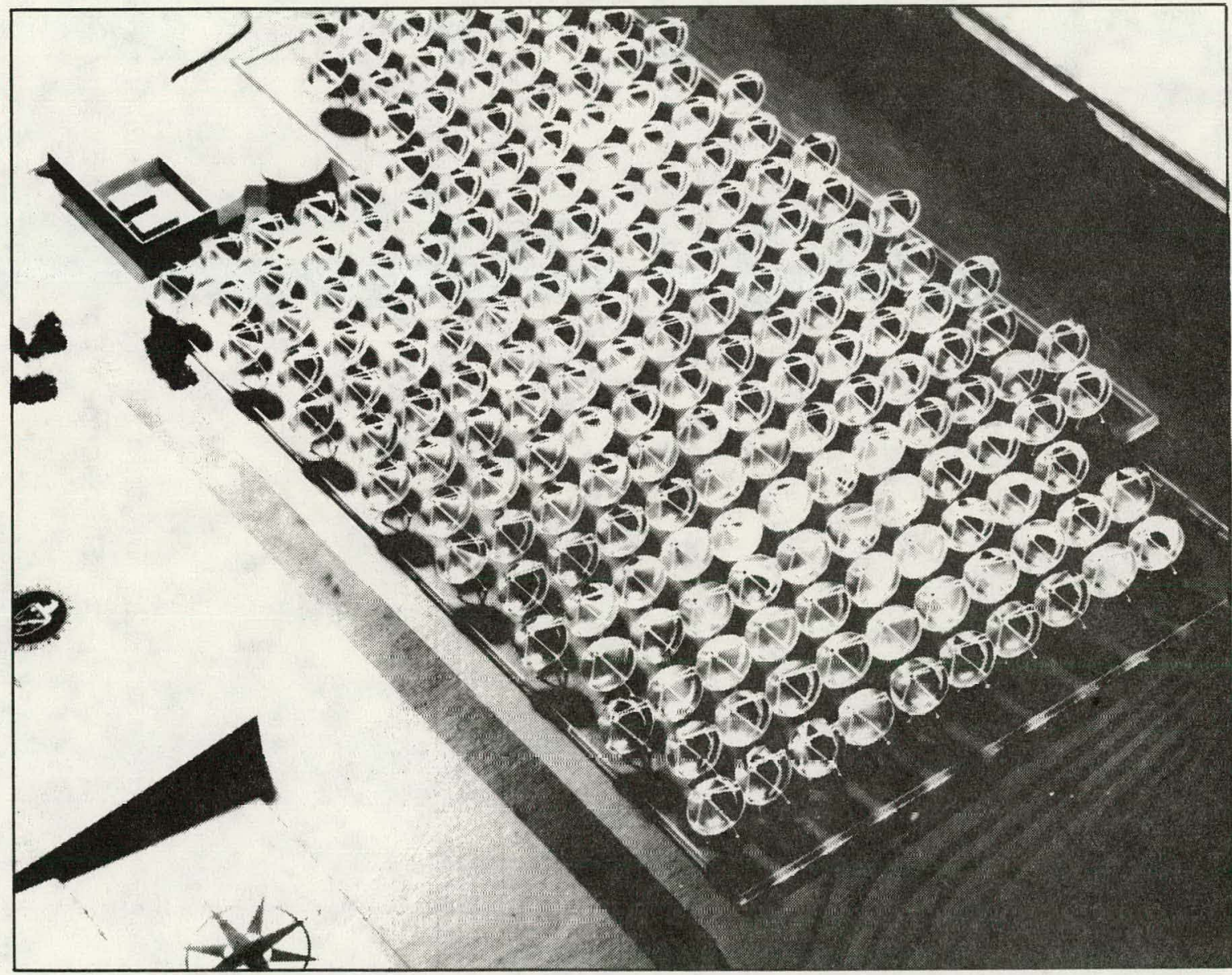

Figure 2-11. Artist's Concept 


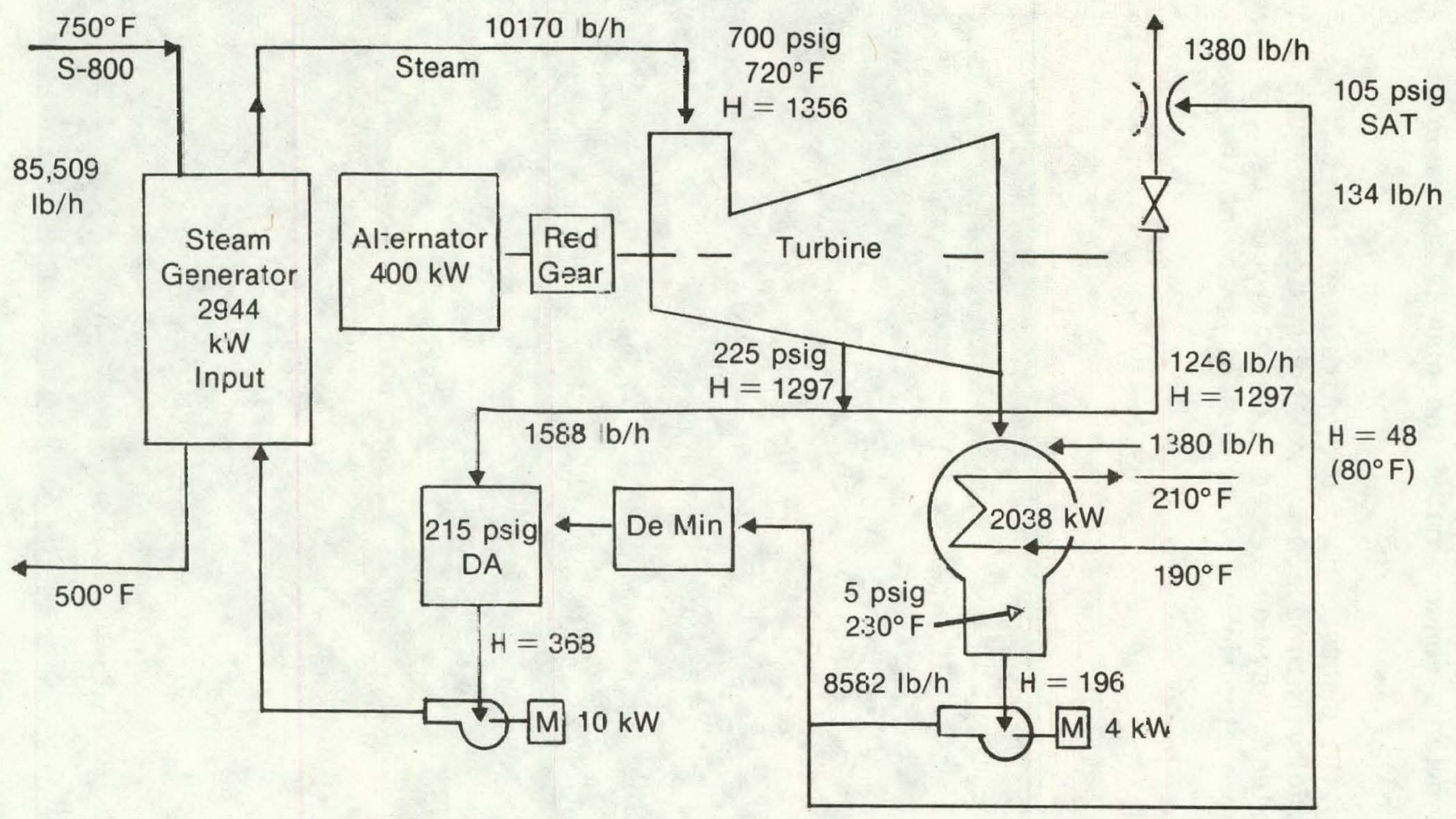

Figure 2-12. Organic Fluid Receiver Reference System, Shenandoah Solar Total Energy System. 


\subsubsection{Shenandoah Reference System}

The reference thermal storage concept is a trickle charge, dual-media system. The concept is as described by G.E. (1978) and is shown in Fig. 2-13. Hot oil from the collector field trickles over a bed of taconite pebbles (iron ore) to charge the storage system. During charging, only one tank has oil trickling through it, and the flow rate is low enough that the tank contains only a small amount of oil. This allows the thermal energy to be stored in the sensible heat of the taconite, which is inexpensive, and mini- mizes the amount of heat transfer oil required. The system is discharged by trickling cold oil through the taconite pebble bed. The reference system capacity is six hours of discharge for a total capacity $17,700 \mathrm{kWh}_{\mathrm{t}}(61 \mathrm{MBtu})$.

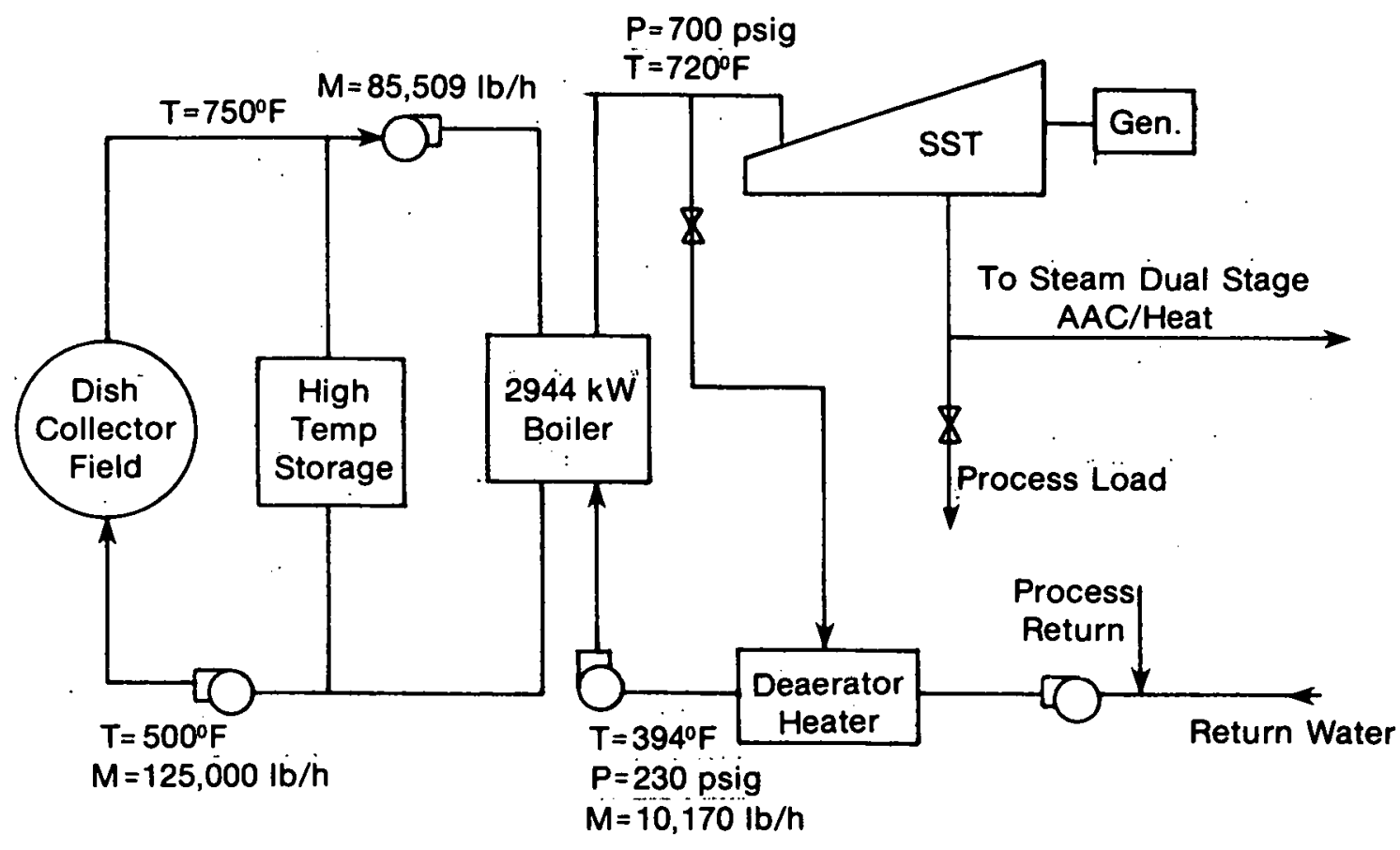

Figure 2-13. Organic Fluid Receiver Reference Thermal Storage System

\subsubsection{Trickle Charge Oil/Glass}

This alternate storage system is identical to the reference system except that the taconite bed is replaced with waste glass. Taconite is not locally available in some locations in the U.S. Unless a source of taconite is available close to the proposed solar plant site, the transportation charges can easily exceed the cost of the taconite. Waste glass is considered to be available in most U.S. locations and, in addition, is less expensive and has better thermal properties than taconite. Although glass was employed in the study, any low-cost solid medium that is compatible with the oil would be a good alternative. 


\subsubsection{K-Salt Storage}

A thermal storage system that uses molten salt is shown in Fig. 2-14. The hot oil from the collector field heats molten salt in a tube and shell heat exchanger. The molten salt, as described before, is a mixture of $\mathrm{NaNO}_{3}, \mathrm{KNO}_{3}$, and $\mathrm{NaNO}_{2}$ and has a melting point of $390^{\circ} \mathrm{F}$. The hot salt is stored with the cold salt in a thermocline tank. The oil/steam generator has been replaced with a salt/steam generator. Pumps for circulating the molten salt have been added. Because of the additional heat exchanger in the system (oil to salt), the temperature of the steam at the turbine inlet decreased by $20^{\circ} \mathrm{F}$ compared to the reference system. The motivation for using the molten salt is that it costs much less than the Syltherm 800. Because the temperatures are low, the tanks are externally insulated, plain carbon steel.

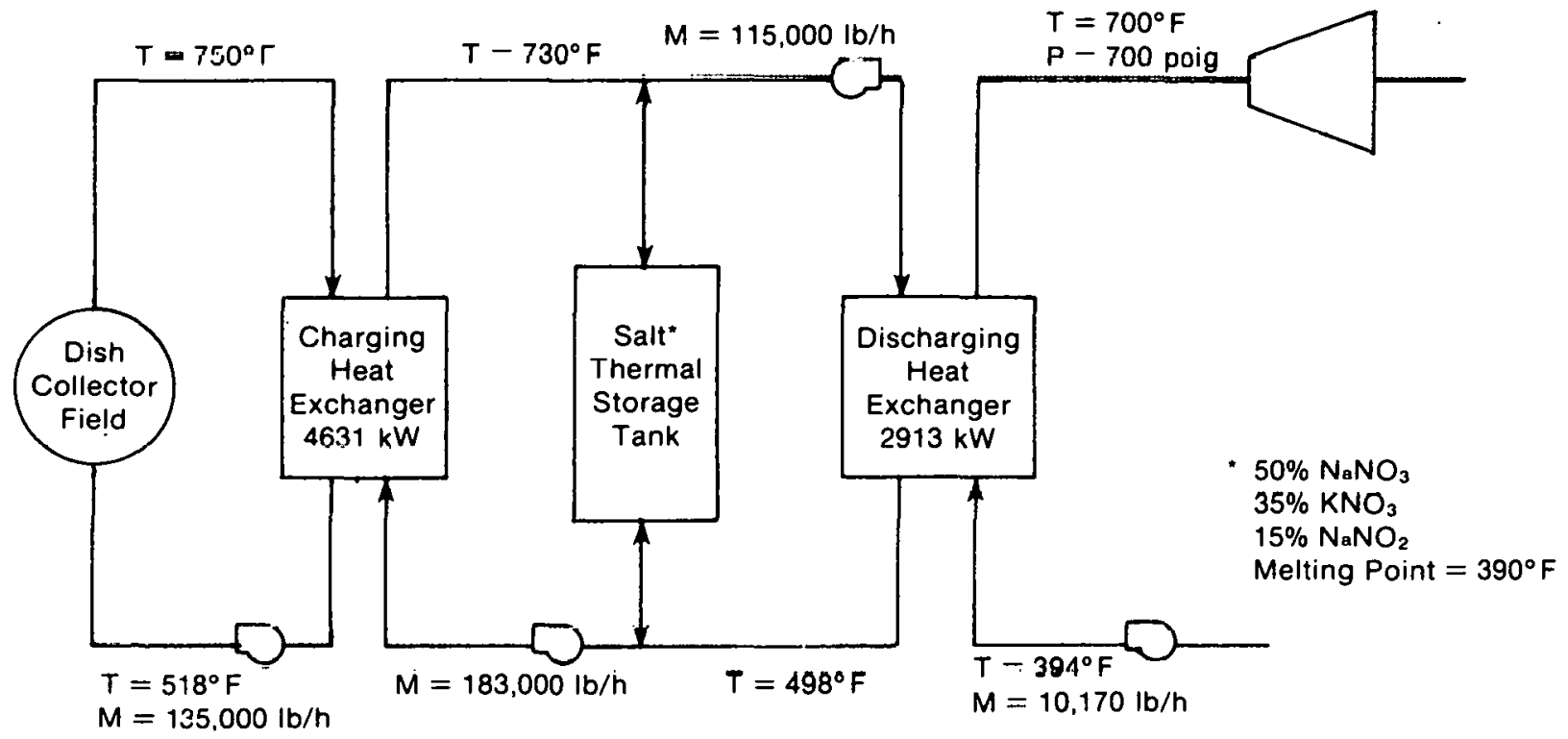

Figure 2-14. Molten Salt Storage for Organic Fluid Receivers

\subsubsection{Salt/Glass}

This thermal storage system is identical to the previous one except that a low-cost solid medium has replaced most of the salt in the thermocline tank (a dual-media thermocline, not trickle charge). This medium was again assumed to have the thermal properties of glass. The intent of considering this system was to determine the benefit of finding a low-cost material compatible with molten salt. The material could be glass, but it could also be a mineral or an industrial waste. 


\subsubsection{Phase Change Storage}

The phase change storage system shown in Fig. 2-15 is based on a concept developed by Lefrois et al. (1979). The energy required to boil the feedwater is stored by melting a mixture of $99 \% \mathrm{NaOH}$ and $1 \% \mathrm{NaNO}_{3}$. This mixture was chosen because upon partial freezing it forms a slush that can be pumped. The heat required to preheat the feedwater and superheat the steam is stored in a trickle charge oil/rock system similar to the baseline system.

In the charging mode, a portion of the hot oil from the collector field flows into the trickle charge tank; the remainder flows into a heat exchanger that melts the salt slush. If steam is generated during charging, the inlet temperature to the field can vary between $587^{\circ} \mathrm{F}$ and $414^{\circ} \mathrm{F}$.

During discharge, steam is generated in the reflux boiler, shown in Fig. 2-15. Molten salt is pumped into a pressure vessel at 1600 psia, where it comes into direct contact with water. The boiling temperature of the water is lower than the melting temperature of the salt, so that the salt freezes as the water boils. The steam then flows to another pressure vessel, where it condenses on the outside of heat exchanger tubes. Water on the inside of the tubes boils at 1000 psi as the water on the outside condenses. Steam is produced at $720^{\circ} \mathrm{F}, 700 \mathrm{psig}$, which is identical to the baseline system.

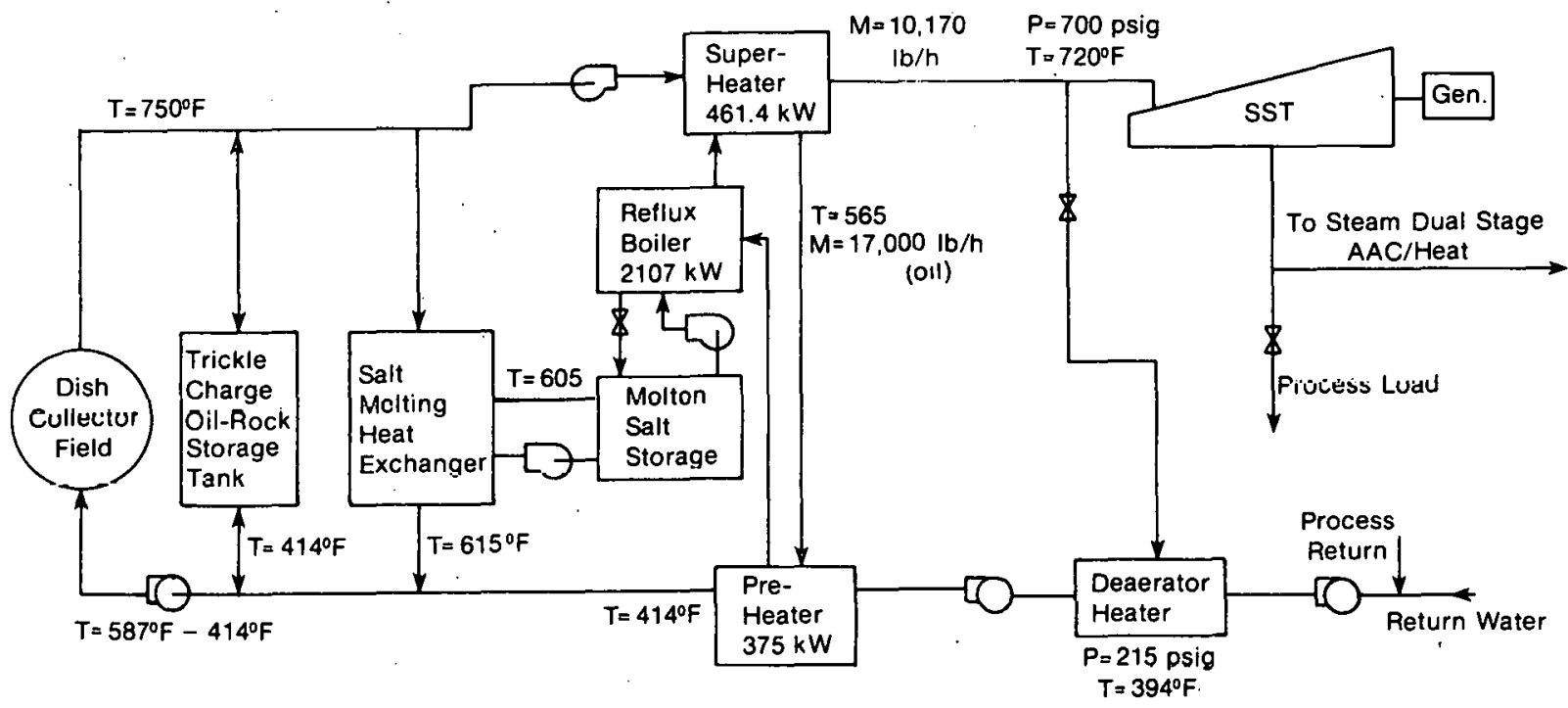

Figure 2-15. Phase Change Storage for Shenandoah Total Energy System 
SER눕 


\section{SECTION 3.0}

\section{THERMAL STORAGE SUBSYSTEM COST AND .PERPORMANCE}

Costs were calculated for the thermal storage systems described in the previous section. Table 3-1 lists the cost of thermal storage systems for water/steam receivers, and Table 3-2 lists the cost of thermal storage systems for organic fluid receivers. Only the direct costs of major pieces of equipment were estimated, and therefore the actual installed costs of these systems would be considerably higher than the costs shown.* All costs are in fourth-quarter 1979 money.

The cost estimates shown in Tables 3-1 and 3-2 are based on cost data from a variety of sources. These include vendor and supplier quotes, previous solar system design studies, and architectural engineering company estimates. As with any cost estimate of this type, they are uncertain. The intent of this study is to be consistent in the cost estimates so that one thermal storage system can be accurately compared to another. For example, a storage system requiring a larger volume of tankage than another will have a higher calculated cost, although there may be some uncertainty in the actual cost. In addition to consistent costing of the storage systems, consistent system design parameters were used. For example, the pinch point temperature difference $(\Delta T)$ of all of the boiling or condensing heat exchangers was designed to be $11^{\circ} \mathrm{C}\left(20^{\circ} \mathrm{F}\right)$ and the same type of heat exchangers were used, etc.

Tables 3-1 and 3-2 present the major cost elements and the cost of each concept for that element. For each concept, the power rating is given for the conditions described in Section 2.0. For the reference water/steam system (oil/rock), the power output is $70 \mathrm{MW}$ from storage. All of the concepts have the same $100-\mathrm{MW}$ output when operating direct. For all of the concepts with an organic fluid receiver, the ratings are $2944 \mathrm{~kW}$ (thermal, into the high-pressure steam turbine) both direct and through storage.

The total cost of each of the thermal storage systems can be broken down into powerrelated and energy-related jtems. This classification is as follows:

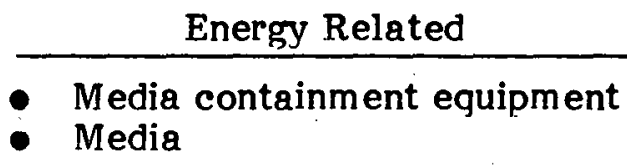

Energy Related

- Media

Power Related
- Media circulation equipment
- Charcharging heat exchangers
- Charging heat exchangers

These cost data were employed to calculate the cost of storage at differing storage capacities.

\footnotetext{
*Based on a data from Hausz et al. (1978), the installed costs including labor, materials, interests, contigencies, and indirects may be calculated as follows:

$$
\text { Total Costs }(\$ / k W)=\left(C_{p}+C_{s} \cdot H\right) \cdot F_{N}
$$

where $\mathrm{F}_{\mathrm{N}}=1.95$ for these types of applications; $\mathrm{C}_{\mathrm{p}}=$ the power-related cost based on major equipment $(\$ / \mathrm{kW}) ; \mathrm{C}_{\mathrm{s}}=$ the energy-related cost based on major equipment $(\$ / \mathrm{kWh})$; and $H=$ the quantity of energy storage (hours).
} 


\section{Table 3-1. COMPARISON OF MAJOR COST ELEMENTS OF THERMAL STORAGE SYSTEMS POR STEAM WATER RECEIVERS}

(3 Hours Storage at Pcwer Output from Storage)

\begin{tabular}{|c|c|c|c|c|c|c|c|}
\hline & Oil/Fock & Draw Salt & K-Salt/Glass & $\begin{array}{c}\text { Two-Stage } \\
\text { Salt }\end{array}$ & $\begin{array}{l}\text { Two-stage } \\
\text { Salt/Glass }\end{array}$ & $\begin{array}{c}\text { Draw Salt/Glass } \\
\text { Oil/Rock }\end{array}$ & Phase Change \\
\hline $\begin{array}{l}\text { Power Output } \\
\text { from Storage }\end{array}$ & $70 \mathrm{MW}$ & $70 \mathrm{MW}$ & $71.8 \mathrm{MW}$ & $80.4 \mathrm{MW}$ & 80.4 MW & $80.4 \mathrm{MW}$ & $74.2 \mathrm{MW}$ \\
\hline $\begin{array}{l}\text { Media Contain- } \\
\text { ment Equipment }\end{array}$ & $\$ 991,000$ & $\$ 1,061,000$ & $\$ 948,000$ & $\$ 2,063,000$ & $\$ 2,287,0010$ & $\begin{array}{r}\$ 2,118,000 \\
1,212,000^{\mathrm{a}}\end{array}$ & $\$ 1,669,000$ \\
\hline $\begin{array}{l}\text { Media Circula- } \\
\text { tion Equipment }\end{array}$ & 3,03इ,0נ0 & $5,316,000$ & $4,220,00 \mathrm{C}$ & $5,922,000$ & $5,922,000$ & $4,133,000$ & $5,514,000$ \\
\hline $\begin{array}{l}\text { Discharge Heat } \\
\text { Exchangers }\end{array}$ & $2,868,0 J 0$ & $1,029,000$ & $1,030,000$ & $1,382,000$ & $1,3 \varepsilon 2,000$ & $1,875,000$ & $1,006,000$ \\
\hline $\begin{array}{c}\text { Charging Heat } \\
\text { Exchangers }\end{array}$ & $2,686,000$ & $1,097,000$ & 863,000 & $1,332,000$ & $1, \approx 32,010$ & $2,276,000$ & $1,121,000$ \\
\hline Media & $1,95:, 000$ & $10,841,000$ & $2: 894,000$ & $10,483,000$ & $3,493,000$ & $2,013,000$ & $6,946,000$ \\
\hline TOTAL & $\$ 11,5 \xi 3,000$ & $\$ 19,344,000$ & $\$ 9,955,003$ & $\$ 21,182,000$ & $\$ 14,416,000$ & $\begin{array}{l}\$ 12,415,000 \\
\$ 11,509,000^{2}\end{array}$ & $\$ 17,256,000$ \\
\hline $\begin{array}{l}\text { Energy-Related } \\
\text { Costs } \\
\left(\$ / k W_{\left.e^{h}\right)}\right.\end{array}$ & 14.08 & 56.68 & 17.84 & 52.01 & 23.96 & $\begin{array}{l}17.13 \\
13.37^{\mathrm{a}}\end{array}$ & 38.70 \\
\hline $\begin{array}{l}\text { Power-Related } \\
\text { Costs } \\
\left(\$ / \mathrm{kW}_{\mathrm{e}}\right)\end{array}$ & 122.70 & 106.31 & 85.14 & 107.40 & 107.40 & 103.03 & 116.45 \\
\hline
\end{tabular}

\footnotetext{
${ }^{a}$ Carbon Steel externally insulated tank.
} 
Table 3-2. COMPARISON OF MAJOR COST ELEMENTS OP THERMAL STORAGE SYSTEMS

For Organic Fluid Receivers

(6 Hours Storage at $2944 \mathrm{~kW}_{\mathrm{t}}$ )

\begin{tabular}{|c|c|c|c|c|c|c|}
\hline & Shenandoah & Oil/Glass & Salt Storage & & Salt/Glass & $\begin{array}{c}\mathrm{NaOH}^{\mathrm{b}} \\
\text { Phase Change }\end{array}$ \\
\hline $\begin{array}{l}\text { Media Containment } \\
\text { Equipmer.t }\end{array}$ & $\$ 167,000$ & $\$ 154,000$ & $\$ 65,800$ & & $\$ 66,500$ & $\$ 124,000$ \\
\hline $\begin{array}{l}\text { Media Circulation } \\
\text { Equipment }\end{array}$ & 169,000 & 169,000 & 286,000 & & 286,000 & 195,000 \\
\hline $\begin{array}{l}\text { Discharge Heat } \\
\text { Exchangers }\end{array}$ & $90,000^{\mathrm{a}}$ & $90,000^{\mathrm{a}}$ & $62,700^{\mathrm{a}}$ & & $62,700^{\mathrm{a}}$ & $71,000^{\mathrm{a}}$ \\
\hline $\begin{array}{l}\text { Charging Heat } \\
\text { Exchangers }\end{array}$ & - & - & 203,000 & & 203,000 & 83,000 \\
\hline Media & 153,000 & 66,000 & 107,000 & . & 44,000 & 220,000 \\
\hline TOTAL & $\$ 512,000$ & $\$ 441,000$ & $\$ 725,000$ & & $\$ 662,000$ & $\$ 693,000$ \\
\hline $\begin{array}{l}\text { Energy-Related Costs } \\
\left(\$ / \mathrm{kW}_{\mathrm{t}} \mathrm{h}\right)\end{array}$ & 18.12 & 12.40 & 9.89 & & 6.32 & 19.47 \\
\hline $\begin{array}{l}\text { Power-Related Costs } \\
\left(\$ / \mathrm{kW}_{\mathrm{t}}\right)\end{array}$ & 57.40 & 57.40 & 177.24 & & 177.24 & 88.00 \\
\hline
\end{tabular}




\subsection{WATER/STEAM RECEIVER COST AND PERPORMANCE}

\subsubsection{Oil/Rock Storage}

The energy- and power-related costs were first calculated for the oil/rock reference system. The costs thus generated have a low energy cost and a high power cost in comparison to the other systems considered. The media cost for oil/rock storage is quite low, as is the media containment cost. In comparison to salt concepts, the heat exchangers are rather high in cost due to the heat transfer characteristics of oil. Salts are better heat transfer media than oil, and heat exchanger sizes and costs are correspondingly lower for salt systems.

\subsubsection{Draw 8alt 8torage}

The simple draw salt storage system, as shown in Table 3-1, yields the highest energyrelated cost of any system considered. This elevated cost is the result of using an expensive salt as the only storage medium and the relatively low temperature difference across the storage tank. The power-related costs are lower than those for the oil/rock reference system due to the improved heat transfer properties provided by using draw salt in place of oil. Also, it should be noted that because of similar outlet steam conditions, the power output of the draw salt storage plant is equivalent to that of the oil/rock storage plant.

\subsection{3 $\mathrm{K}$-Salt/Glass Storage}

By incorporating the cost advantages of an inexpensive storage medium in a salt system, the energy cost becomes significantly lower than that for the salt-only system. The power-related costs in this system are lower than the previous salt system. The higher $\Delta \mathrm{T}$ across the storage tank lowers the salt flow rates in the system. The lower melting temperature of this salt also reduces the amount of high-quality heat required to preheat the feedwater. The power output is slightly greater from this storage system than from the reference and draw salt systems as a result of the improved outlet steam condition.

\subsubsection{Two-stage Salt Storage}

As would be expected, using two-stage, salt-only storage creates a very high media cost and, correspondingly, a high energy cost. Also contributing to this escalated energy cost is the higher media containment cost, which is dictated by the use of a stainless steel tank for the high-temperature storage unit.

The required areas of the heat exchangers for this system are somewhat larger than for the other salt systems because of the smaller temperature differences across the heat exchanger. This increase in area along with an increase in pump costs produces a powerrelated cost that is much higher than the $\mathrm{K}$-salt/glass power cost. The pump costs are higher because each stage requires separate charging and discharging pumps.

As Table 3-1 shows, the power output of this two-stage salt system is $80.4 \mathrm{MW}$, which is significantly greater than the power provided by the systems described above. This is due to the improved outlet steam conditions. 


\subsubsection{Two-Stage Salt/Glass Storage}

As before, the purpose of considering a dual-media salt system is to minimize cost, particularly by decreasing media cost. Altering the two-stage salt system to a two-stage salt/glass system accomplishes the media cost reduction, and involves only a minor increase in media containment costs. The resulting energy-related cost is reduced from the two-stage salt system. The power-related costs and the power output of this system are equal to those of the two-stage salt system.

\subsubsection{Draw Salt/Glass, Oil/Rock Storage}

Converting the low-temperature storage from $\mathrm{K}$-salt/glass to oil/rock further reduced the media cost, and yielded one of the lowest energy-related costs. Also, as noted in Table 3-1, the energy cost drops to the lowest value calculated, provided that the hightemperature media containment tank need not be stainless steel. Instead, an externally insulated carbon steel structure is used. Additional work is needed to determine the appropriate tank, but was beyond the scope of this study.

The power available from the system is $80.4 \mathrm{MW}$, based on outlet steam conditions. The power-related costs are similar to those of other salt systems, although the heat exchanger costs are somewhat higher and the circulation costs lower than the two-stage salt concepts. These differences in costs are due to the use of oil as a working fluid; the oil/steam heat exchangers must be larger because of the heat transfer characteristics of oil, but the oil pumps are smaller because of the higher heat capacity of oil.

\subsubsection{Phase Change Storage}

Estimating the costs of phase change storage components suggests that both the energyand power-related costs associated with the system are comparatively high. The media cost is high, because $40 \%$ more salt must be used to maintain a maximum $60 \%$ solid slush. The other primary cost driver is the media circulation equipment, since the salt pumps required for this system must circulate and pressurize a very large volume of salt. The gross power output of the phase change system is about $92 \mathrm{MW}$, but the parasitic power losses associated with the system, particularly the reflux boiler salt pump, reduce the output to $71 \mathrm{MW}$.

\subsubsection{Improved Phase Change}

The improved phase change system is very similar to the previous concept. The significant differences are:

- an assumed (but not identified) reduction in the power-related costs of $\$ 21 / \mathrm{kW}_{\mathrm{e}}$; and

- increasing the the net electrical output to $81 \mathrm{MW}$ from storage with a reflux boiler salt pressure recovery turbine.

How these improvements might be obtained was not determined. This analysis is being conducted to determine if such an $R \& D$ project would be worthwhile. 


\subsection{COST AND PERFORMANCE OF THERMAL STORAGE FOR ORGANIC FLUID}

\subsubsection{Shenandoah Reference System}

The cost estimate for the trickle charge of the rock thermal storage system in the Shenandoah reference system is shown in Table 3-2. The cost estimate for the media circulation equipment is from a General Electric internal memo. The discharge heat exchangers (steam generators) were not included in the cost estimate, because they would be required in the system if it had no storage. There are no charging heat exchangers in this system, because the thermal storage fluid is heated in the collector field.

\subsubsection{Oil/Glass Trickle Change}

Replacing the taconite with a waste glass in this system reduces both the media and media-containment costs. The containment costs decrease because the glass has a high volumetric heat capacity. The cost of the waste glass was assumed to be $\$ 10$ per ton delivered to the site.

\subsubsection{K-Salt Storage}

The molten salt in this system substantially reduces the energy-related costs compared to the reference system. However, because the salt has a lower heat capacity than the oil in the reference system, the media circulation equipment costs are higher. The discharge heat exchangers are smaller in this system, because the salt has a higher thermal conductivity than the oil. This system is given credit for this cost reduction. The oil-tosalt heat exchanger significantly adds to the power-related cost of this system.

\subsubsection{Salt/Low-Cost Media Storage}

The energy cost of the previous system was reduced further by replacing most of the molten salt in the storage tank with a low-cost material similar to waste glass. The cost of this material was also assumed to be $\$ 10$ per ton delivered to the site.

\subsubsection{Phase Change Storage}

This system has the highest energy-related costs of any of the alternate thermal storage concepts. This is partly due to the assumed incomplete freezing (60\%) of the salt, which is required to allow it to be pumped. The charging heat exchanger costs are lower in this system than in the salt storage systems due to the lower heat rate (only the heat required for boiling is stored in the phase change salt) and a higher temperature difference in the heat exchanger. The parasitic electric power required to operate this system is large, $200 \mathrm{~kW}_{\mathrm{e}}$, compared to the plant electrical output, $400 \mathrm{~kW} \mathrm{e}$ 


\section{SECTION 4.0}

\section{RANKING OF THERMAL STORAGE CONCEPTS}

The thermal storage concepts are ranked according to their impact on the solar thermal system delivered-energy unit cost. In Section 4.1, the method of ranking the concepts is briefly described. In Section 4.2, the results of the analyses are presented for a water/steam collector/receiver; and in Section 4.3, the results are presented for the organic fluid collector/receiver.

\subsection{THE RANTKING INDEX}

The ranking of the concepts is based on the unit energy cost from the storage-coupled solar thermal plant. An identical (normalized) ranking is achieved if that cost is divided by the cost of the first-generation reference system. The ratio is defined as the ranking index (RI):

$$
\mathrm{RI}=\frac{\left[\frac{\text { Cost of Alternative (A) }}{\text { Quantity of Energy (A) }}\right]}{\left[\frac{\text { Cost of Reference (R) }}{\text { Quantity of Energy (R) }}\right]}
$$

where $A$ denotes the alternate concepts and $R$ the reference system. A method for evaluating the ranking index has been derived (Copeland 1980); methods suitable for stand-alone electric power plants and cogeneration have also been prepared.

Note that a ranking index less than unity indicates a reduction in the unit energy cost of the system. The percent change in unit cost is simply RI minus one multiplied by 100 . A negative percent change in the unit energy cost is the desired cost reduction.

Costs in the above equation are the sum of all the individual costs, including:

- equipment

- solar collector

- thermal storage

- conversion equipment

- land

- etc.

- installation

- nondirects

- contingency and spares

- indirects

- interest during construction

- operation and maintenance (O\&M)

- backup energy (fuel and/or electricity). 
Where costs are annually occurring (O\&M, fuel), they are levelized in accordance with a procedure given in the EPRI Technical Assessment Guide (1979).

The ranking is done in a way that eliminates the influence of all parameters except the thermal storage concepts. The following constraints are applied to the analysis of the thermal storage concepts, $\mathrm{A}$ and $\mathrm{R}$ :

- The collector/receiver fields are the same size, and the nameplate ratings on the plant are also the same.

- The plants are at the same location.

- The plants are being dispatched in the same manner.

- The same energy conversion system is employed (but the thermodynamic static points of the working fluid may differ).

- The plants have the same capacities to receive, store, and dellver thermal ,energy. (The electrical ratings from storage may differ.)

The costs are evaluated using exactly the same costs for the collector field conversion equipment, etc., except as these items are affected by the alternative thermal storage concept. Since the remaining system costs are the same for all concepts, the effect of any uncertainties in the common equipment cost is minimized. Similarly, the performance items are analyzed and the concepts are ranked when performing the same mission. The thermal storage concepts are not required to deliver the same quantity of usable energy (heat, electricity, or both). In general, the quantities of energy delivered are different due to variations in the efficiencies (i.e., performance) of the thermal storage concepts. The ranking index focuses on the differences due to the thermal storage conc'epts.

\subsection{RESULTS POR WATER/STEAM COLLECTOR/RECEIVER}

\subsubsection{Cost Data for Water/Steam}

In this section, the results of the cost calculations for water/steam collector/receiver systems are presented. The cost of each concept is taken from Section 3.0, which presented the data on a cost per $\mathrm{kW}_{\mathrm{e}}$ and per $\mathrm{kWh}$. Table 4-1 presents the same data for both an electric and thermal basis. The only difference in the two data bases is the cycle efficiency when operating through storage. The concepts were analyzed when each has the same thermal discharge rating.

\subsubsection{Performance Data for Water/Steam}

The ranking index provides the relationship of cost and performance (efficiency). Three efficiencies of the thermal storage subsystem are required for the analysis (Copeland 1980):

- First law (heat losses through insulation; heat to heat);

- Power-cycle conversion efficiency (heat to work); and

- Collector/receiver (insolation to heat). 
Table 4-1. PRELIMINARY COST DATA FOR STORAGE WITH WATER/STEAM RECEIVERS

Total Costs ${ }^{\mathrm{C}}\left(\$ / \mathrm{kW}_{\mathrm{e}}\right)=\left(\mathrm{C}_{\mathrm{p}}+\mathrm{C}_{\mathrm{s}} \cdot \mathrm{H}\right) \cdot \mathrm{F}_{\mathrm{N}}$

\begin{tabular}{|c|c|c|c|c|c|}
\hline \multirow[b]{2}{*}{ Concept } & \multicolumn{2}{|c|}{$\begin{array}{l}\text { Power-Related Costs } \\
C_{p}\end{array}$} & \multicolumn{2}{|c|}{$\begin{array}{c}\text { Energy-Related Costs } \\
\mathrm{C}_{\mathbf{s}}\end{array}$} & \multirow[b]{2}{*}{ Comments } \\
\hline & $\left(\$ / \mathrm{kW}_{\mathrm{e}}\right)$ & $\left(\$ / k W_{t}\right)$ & $\left(\$ / k W h_{e}\right)$ & $\left(\$ / k W h_{t}\right)$ & \\
\hline Oil/Rock & 122 & 30.3 & 14 & 3.5 & Reference system \\
\hline Draw Salt ${ }^{\mathrm{a}}$ & 106 & 26.3 & 57 & 14.0 & Thermocline, salt only \\
\hline $\mathrm{K}-$ Salt/Glass ${ }^{\mathrm{b}}$ & 85 & 21.2 & 18 & 4.4 & $\begin{array}{l}\text { Recycled glass or other } \\
\text { low-cost media }\end{array}$ \\
\hline & $\mathrm{K}$-Solt melts ot $390^{\circ} \mathrm{F}$ \\
\hline Phase Change $\mathrm{NaNO}_{3}$ & 116 & 27.4 & 39 & 9.0 & Throttling \\
\hline Improved Phase Change & 95 & 24.3 & 35 & 9.0 & $\begin{array}{l}\text { Pressure recovery and } \\
\text { cost reduction, } \mathrm{NaNO}_{3}\end{array}$ \\
\hline \multicolumn{6}{|l|}{ Two Stage: Draw Salt/ } \\
\hline Glass and $\mathrm{K}-$ Salt/Glass & 107 & 27.9 & 24 & 6.2 & \\
\hline \multicolumn{6}{|l|}{ Two Stage: Draw Salt/ } \\
\hline Glass and Oil/Ro & 103 & 26.7 & $\begin{array}{l}17 \\
(13)\end{array}$ & $\begin{array}{l}4.45 \\
(3.5)\end{array}$ & $\begin{array}{l}\text { Stainless steel tank } \\
\text { (Carbon steel tank) }\end{array}$ \\
\hline
\end{tabular}

${ }^{2}$ Draw Salt: $50 \% \mathrm{NaNO}_{3}, 50 \% \mathrm{KNO}_{3}$.

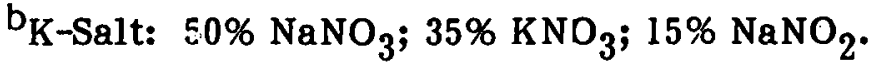

${ }^{c} \mathrm{~F}_{\mathrm{N}}$ accounts for labor and nondirects; based on Hausz et al. (1978) data, $\mathrm{F}_{\mathrm{N}}=1.95$ in this approach. 
Each efficiency is evaluated [using the procedures of Copeland (1980) and the concepts and data of Section 2.0] for each concept and is divided by the same efficiency item for the reference concept. The three ratios are multiplied together to yield a product. That product is presented in Table 4-2. The process is repeated for the same efficiency factors when operating direct (i.e., not through thermal storage). For all the concepts studied, the storage and the power plant are totally decoupled when operating direct; for this condition, the product of the ratios is obviously one (unchanged). When operating through storage, there were minor variations due to the first law and collector/receiver performance. The biggest changes in efficiency were due to improvements in the powercycle operating conditions.

Table 4-2. PRELIMINARY PERPORMANCE DATA FOR CONCEPTS WITH WATER/STEAM RECEIVERS

\begin{tabular}{|c|c|c|c|}
\hline Concept & $\begin{array}{l}\text { Product of } \\
\text { Efficiency } \\
\text { Ratios, } \\
\text { Storage }\end{array}$ & $\begin{array}{l}\text { Product of } \\
\text { Efficiency } \\
\text { Ratios, } \\
\text { Direct }\end{array}$ & Comments \\
\hline Oil/Rock & 1.0 & 1.0 & Reference \\
\hline Draw Salt ${ }^{\mathbf{a}}$ & 1.0 & 1.0 & $\begin{array}{l}\text { Salt only } \\
\text { in thermocline }\end{array}$ \\
\hline K-Salt/Glass ${ }^{b}$ & 1.0 & 1.0 & $\begin{array}{l}\text { Low-cost recycled } \\
\text { glass in thermocline }\end{array}$ \\
\hline $\begin{array}{l}\text { Two Stage: Draw Salt } \\
\text { and } \mathrm{K} \text {-Salt }\end{array}$ & 1.07 & 1.0 & $\begin{array}{l}\text { Salts only in two } \\
\text { thermocline tanks }\end{array}$ \\
\hline Phase Change $\mathrm{NaNO}_{3}$ & 1.092 & 1.0 & Throttling \\
\hline $\begin{array}{l}\text { Two Stage: Draw Salt/ } \\
\text { Glass and K-Salt/Glașs }\end{array}$ & 1.07 & 1.0 & $\begin{array}{l}\text { Low-cost media } \\
\text { in twn thermonline } \\
\text { tankg }\end{array}$ \\
\hline $\begin{array}{l}\text { Two Stage: Draw Salt/ } \\
\text { Glass and Oil/Rock }\end{array}$ & 1.07 & 1.0 & . \\
\hline Improved Phase Change & 1.191 & 1.0 & $\begin{array}{l}\text { Pressure recovery and } \\
\text { capital cost reductions }\end{array}$ \\
\hline
\end{tabular}




\subsubsection{Plant Cost Breakdown}

Figure 4-1 presents the cost breakdown of the Barstow technology reference system.* The nameplate rating for this plant is $100-\mathrm{MW}$ direct and $70 \mathrm{MW}$ from storage for three hours (i.e., $210 \mathrm{MWh}$ from storage). All costs were calculated for an $\mathrm{n}$ th commercial plant. The DOE cost goals were employed for the heliostats and the receiver/tower. The power plant costs were that of conventional steam generation equipment. The balance of plant costs include land, controls, buildings, etc. Operations and maintenance (O\&M) costs were levelized over a 30 -year period and then capitalized using fixed charge rates typical of investor-owned utilities (EPRI 1979). The thermal storage costs represent only $6.7 \%$ of the system costs. The goal of the program is to reduce the thermal storage subsystem cost by more than 24\%; that goal is equivalent to a reduction in the busbar energy cost $(\mathrm{BBEC})$ of $1.6 \%$ or more at these conditions.

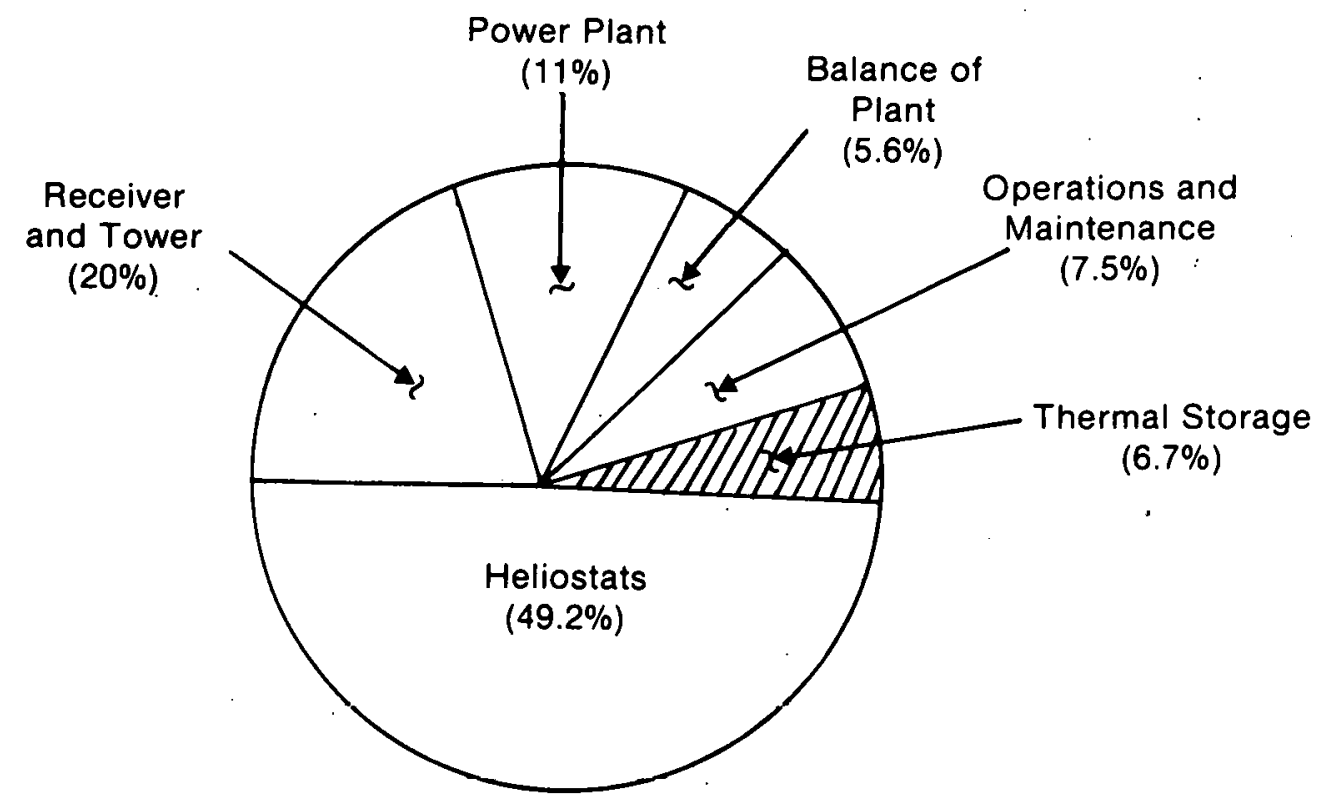

Figure 4-1. Cost Breakdown of Reference Water/Steam Collector/Receiver (Barstow Technology $100 \mathrm{MWe} / 70 \mathrm{MWe} 1.0 \mathrm{~km}^{2}$ Collector Area and 3 Hours of Thermal Storage)

*A similar distribution for slightly different conditions is given in Sandia (1977). 


\subsubsection{Appropriate Storage and Collector Area Combinations}

The analysis seeks to identify promising thermal storage concepts for solar thermal applications. The number of combinations of storage capacity and field size is large merely for electric power applications. The actual design conditions for a given site and application must be specified by the individual user. Due to differences in insolation, load profiles, and desired mission, varied combinations of storage and collector areas are anticipated for the many users. Analyses (Melton 1978) have been conducted and have verified this variation; however, the same studies also indicate that there are appropriate ranges for large electric utilities. (Clearly, a small collector area with a relatively large quantity of storage is not appropriate.) Table 4-3 presents the appropriate range of storage capacities for each of three collector areas. These data (Melton 1978) are for a stand-alone Barstow technology plant, which is the referepce system in these studies. The best conditions occur with a collector area of $1.0 \mathrm{~km}^{2}$. Three hours of storage is about the best overall design condition, or nominal, at that collector area (for the sites and utilities studied).

Table 4-3. APPROPRIATE AREA AND STORAGE CAPACITY COMBINATIONS ${ }^{\mathrm{a}}$

\begin{tabular}{|c|c|c|}
\hline Area & Storage Capacity & Comments \\
\hline $0.5 \mathrm{~km}^{2}$ & about 1 Hour & Buffer only \\
\hline $1.0 \mathrm{~km}^{2}$ & 2-5 Hours & $\begin{array}{l}\text { Depends on location and time } \\
\text { frame }\end{array}$ \\
\hline $1.5 \mathrm{~km}^{2}$ & 5-9 Hours & $\begin{array}{l}\text { Depends on location and time } \\
\text { frame }\end{array}$ \\
\hline $\begin{array}{l}{ }^{4} \text { For a } \\
\text { Technol }\end{array}$ & $\mathrm{MW}_{\mathrm{e}} / 70-\mathrm{MW}_{\mathrm{e}}$ solar & thermal plant with Barstow \\
\hline
\end{tabular}

The insolation patterns, and the load profile of a user vary geographically and impact "dispatch strategy." Dispatch strategy determines the relative use of storage, i.e., the quantities of energy delivered through storage and direct (not through storage). User differences prevent any one strategy of storage use from being optimum. Again, there are only ranges about a nominal, based on the expected needs of many users.

\subsubsection{Comparison of Concepts}

The rankings of concepts based upon busbar energy cost are presented in this section. The rankings were conducted for the range of thermal storage capacities at three collector areas. Two dispatch strategies were also investigated. One is designed to meet an evening peak load; that strategy is identified as "high storage use." The other strategy is oriented toward generating power in daylight hours and storing the excess thermal energy (beyond the turbine nameplate usage rate); that strategy is identified as "low storage use." 


\section{Comparison with $0.5-\mathrm{km}^{2}$ Collector Area}

Figure 4-2 presents the percent change in busbar energy costs of a solar thermal system with various thermal storage concepts, a $0.5-\mathrm{km}^{2}$ collector area, and low storage use. For the nominal storage capacity, the concepts rank as follows:

\section{$0.5-\mathrm{kM}^{2}$ Collector Area}

\begin{tabular}{|c|c|c|}
\hline Concept & $\begin{array}{l}\text { Reduction in BBEC } \\
\text { of the System }\end{array}$ & $\begin{array}{l}\text { Equivalent Improvement in } \\
\text { Thermal Storage Costs }\end{array}$ \\
\hline K-Salt/Glass & $3 \%$ & $25 \%$ \\
\hline $\begin{array}{l}\text { Two-Stage } \\
\text { Draw Salt/Glass } \\
\text { and Oil/Rock }\end{array}$ & $1.8 \%$ & $12 \%$ \\
\hline $\begin{array}{l}\text { Two-Stage } \\
\text { Draw Salt/Glass } \\
\text { and K-Salt/Glass }\end{array}$ & $1.2 \%$ & $8 \%$ \\
\hline $\begin{array}{l}\text { Improved Phase } \\
\text { Change } \mathrm{NaNO}_{3}\end{array}$ & $1 \%$ & $6 \%$ \\
\hline Oil/Rock (Reference) & $0 \%$ & $0 \%$ \\
\hline
\end{tabular}

The remaining concepts did not offer an improvement. Of the above, only one concept, the K-salt/glass, had the potential of meeting the program goal of greater than $20 \%$ improvement in thermal storage subsystem cost.

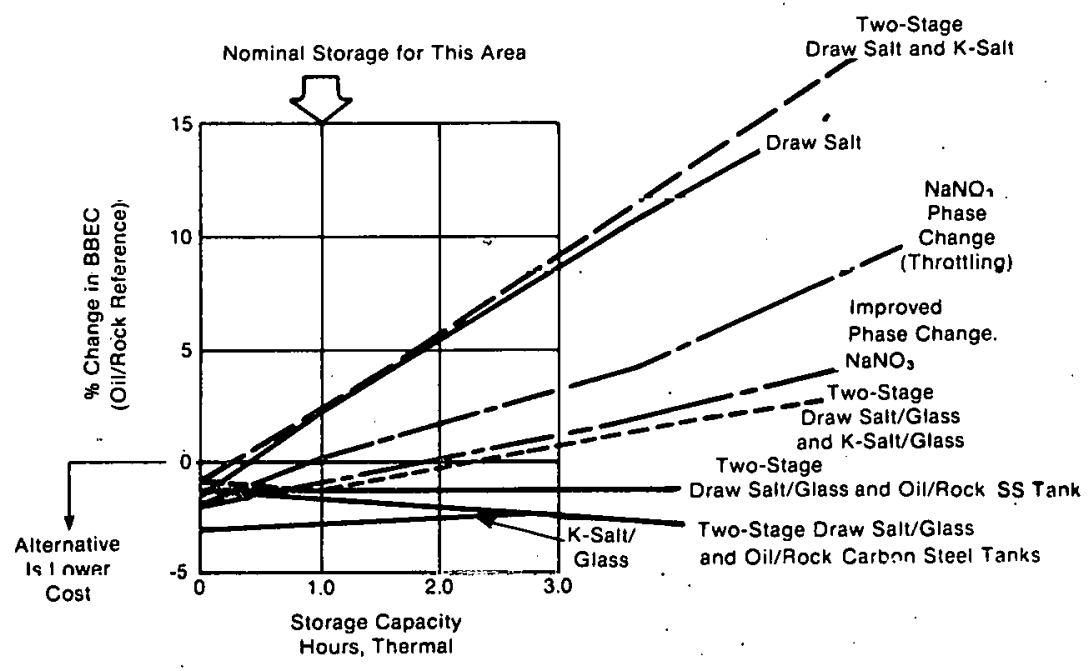

Figure 4-2. Comparison of Concepts at $0.5 \mathbf{~ k m}^{2}$ Collector Area

\section{Low Storage Use}




\section{Comparison with $1.0-\mathrm{km}^{2}$ Colleetor Area}

Figure 4-3 presents the percent change in bysbar energy of a solar thermal system with various thermal storage concepts, a $1.0-\mathrm{km}^{2}$ collector area, and high storage use. For the nominal storage capacity (three hours), the concepts rank as follows:

\section{$1.0-\mathrm{km}^{2}$ Collector Area}

\begin{tabular}{lcc}
\hline \multicolumn{1}{c}{ Concept } & $\begin{array}{c}\text { Reduction in BBEC } \\
\text { of the System }\end{array}$ & $\begin{array}{c}\text { Equivalent Improvement in } \\
\text { Thermal Storage Costs }\end{array}$ \\
\hline $\begin{array}{l}\text { Two-Stage } \\
\text { Draw Salt/Glass } \\
\text { Oil/Rock }\end{array}$ & 1.5 to $2.0 \%$ & 22 to $30 \%$ \\
$\begin{array}{l}\text { K-Salt/Glass } \\
\text { Improved Phase } \\
\begin{array}{l}\text { Chunge NuNO } \\
\text { Two-Stage }\end{array}\end{array}$ & $1.2 \%$ & $16 \%$ \\
$\begin{array}{l}\text { Draw Salt/Glass } \\
\text { and K-Salt/Glass }\end{array}$ & $1.1 \%$ & $15 \%$ \\
Oil/Rock (Reference) & $0 \%$ & $0 \%$ \\
\hline
\end{tabular}

The remaining concepts did not offer an improvement. Of the above, only the two-stage, draw salt/glass, and oil/rock concept has the potential of meeting the program goal.

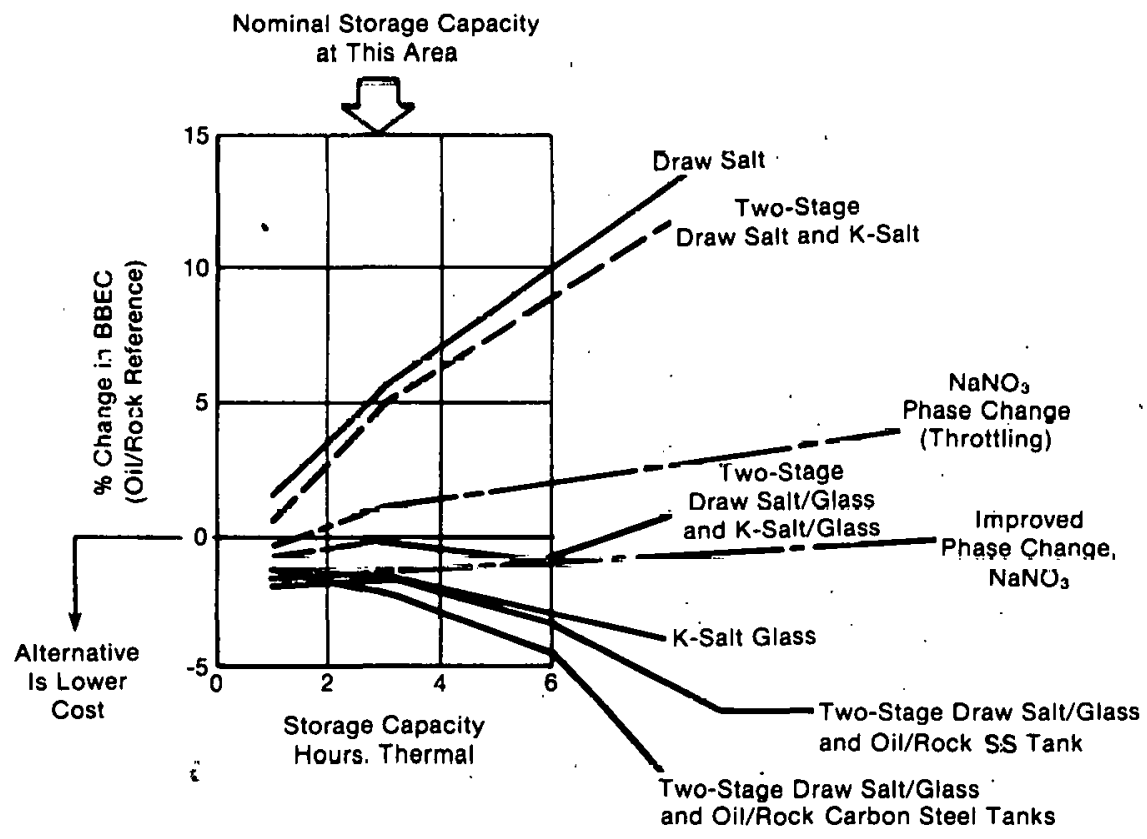

Figure 4-3. Comparison of Concepts at $1.0 \mathrm{~km}^{2}$ Collector Area High Storage Use 
$i$

\section{Comparison with $1.5-\mathrm{km}^{2}$ Collector Area}

Figure 4-4 presents the percent change in busbar energy costs of a solar thermal system with varying thermal storage, a $1.5-\mathrm{km}^{2}$ collector area, and high storage use. For the nominal storage capacity, the concepts rank as follows:

\section{$1.5-\mathrm{km}^{2}$ Collector Area}

\begin{tabular}{lcc}
\hline Concept & $\begin{array}{c}\text { Reduction in BBEC } \\
\text { of the System }\end{array}$ & $\begin{array}{c}\text { Equivalent Improvement in } \\
\text { Thermal Storage Costs }\end{array}$ \\
\hline $\begin{array}{l}\text { Two-Stage } \\
\text { Draw Salt/Glass }\end{array}$ & 1.5 to $2.0 \%$ & 16 to $21 \%$ \\
$\begin{array}{l}\text { Oil/Rock } \\
\text { K-Salt }\end{array}$ & $0.7 \%$ & $7 \%$ \\
$\begin{array}{l}\text { Improved Phase } \\
\text { Change NaNO }\end{array}$ & $0.4 \%$ & $4 \%$ \\
Oil/Rock (Reference) & $0 \%$ & $0 \%$ \\
\hline
\end{tabular}

The remaining concepts did not offer an improvement. As before, only the two-stage draw salt/glass and oil/rock concept comes close to meeting the program goal.

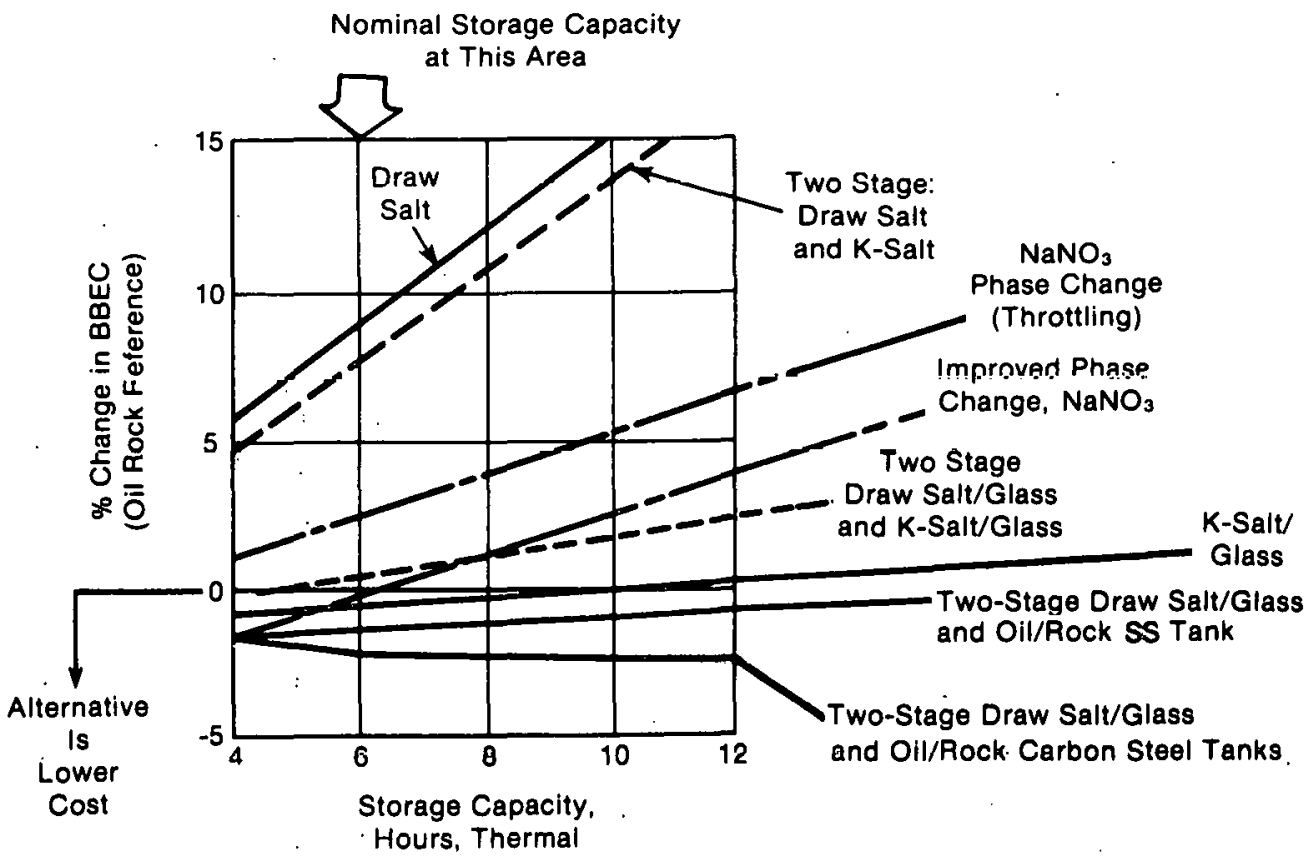

Figure 4-4. Comparison of Concepts at $1.5 \mathrm{~km}^{2}$ Collector Area and High Storage Use 


\section{Comparison with a $\pm 20 \%$ Cost Variation in the Thermal Storage Subsystem}

As preyiously noted, the best cost/benefit condition occurs with a collector area of $1.0 \mathrm{~km}^{2}$ and about three hours of storage. The effect of $\pm 20 \%$ variation in the cost of the thermal storage subsystem has been analyzed for that condition. The objective of this analysis is to test the results of the previous cost analyses, recognizing that there is uncertainty in the projected costs of all of the concepts. Figure 4-5 presents the results. The data for $\mathrm{L}$ (low) and $\mathrm{H}$ (high) are the effect of dispatch strategy on the analysis. When the efficiency of a concept is the same as the reference system, the dispatch system does not affect the results. When there is a difference, the results depend upon whether there is (or is not) an improvement in plant performance. The top and bottom of each bar is the percent change in BBEC for that concept at the $20 \%$ increase and $20 \%$ decrease in subsystem costs, respectively.

Three concepts clearly stand out as undesirable:

- Draw Salt

- Two-Stage Salt, Draw-Salt and K-Sàlt

- $\mathrm{NaNO}_{3}$ Phase Change-(Throttling).

Only at the lowest cost of the above and the highest cost of the reference oil/rock system is there any advantage for those concepts, and even then the difference is not significant.

Three other concepts are approximately equivalent to the reference system:

- Improved $\mathrm{NaNO}_{3}$ Phase Change

- Two-Stage, Draw Salt/Glass and K-Salt/Glass

- Two-Stage, Draw Salt/Glass and Oil/Rock with Stainless Steel Salt Tank.

The. range of uncertainty is sufficiently large that any of the above may prove to be lower or higher in cost than the reference system.

Two concepts appear to have a distinct advantage:

- K-Salt/Glass

- Two-Stage, Draw Salt/Glass and Oil/Rock with Carbon Steel Salt Tank.

At the extreme cost estimates, these concepts could be as much as a $5 \%$ reduction or a $2 \%$ increase in BBEC.

This analysis has indicated the effect of a cost uncertainty on the results of the rankings. The range of $\pm 20 \%$ cost variation in the thermal storage subsystem is arbitrary; the true level of uncertainty may be much greater. Indeed, some of the concepts may not even be viable at any cost. Parallel developments of concepts is clearly a good way to minimize the impact of such risks if program resources are adequate. 


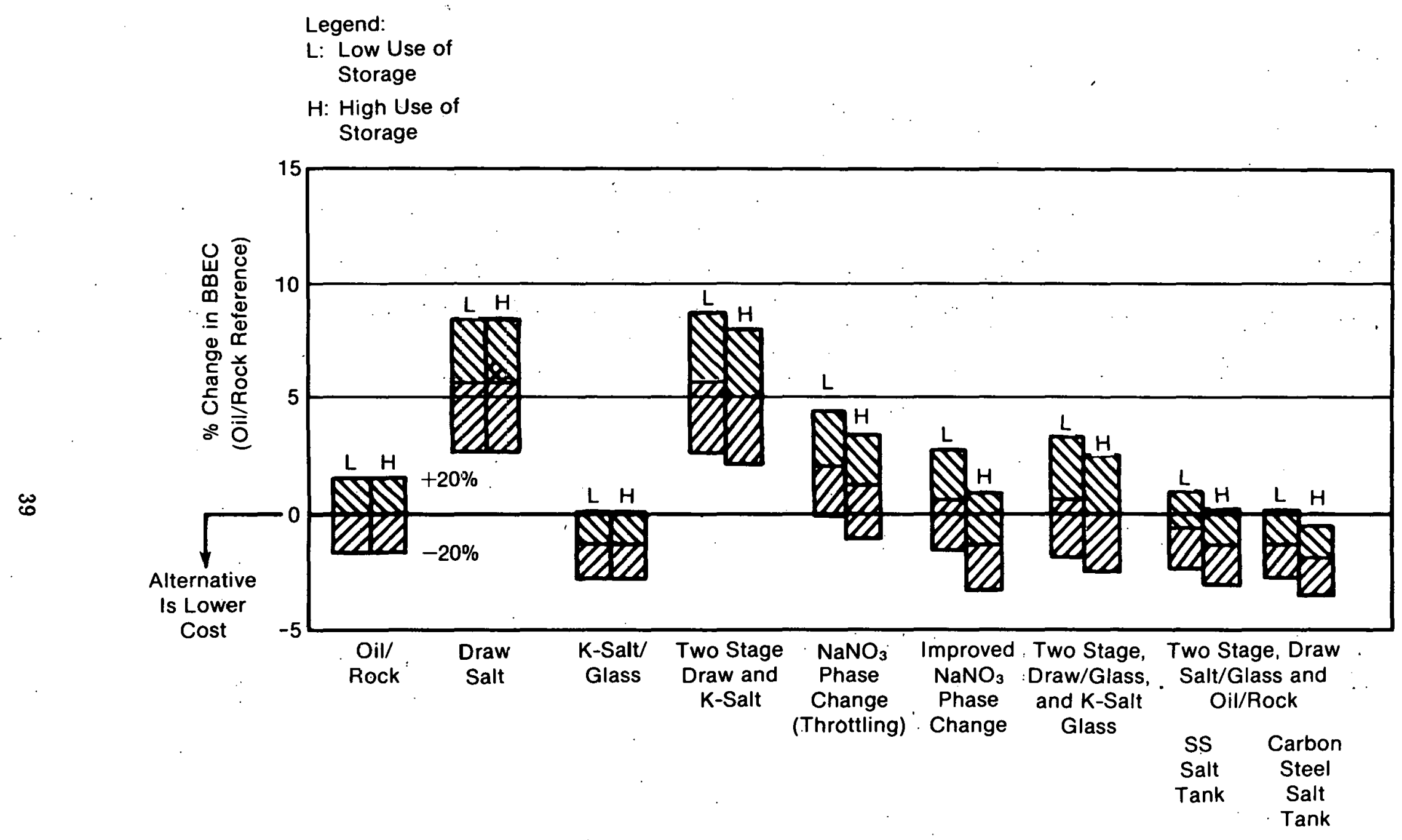

Figure 4-5. Comparison of Concepts with $\pm 20 \%$ Variation in Thermal Storage Subsystem Cost with Water/Steam Receiver, 3 Hours Storage Capacity, and a $1.0 \mathrm{~km}^{2}$ Collector Area $\left(210 \mathrm{MWh}_{e} \approx 600 \mathrm{MWh}\right.$ ) 


\subsection{RESULTS POR ORGANIC FLUID COLLECTOR/RECEIVER}

\subsubsection{Cost Data for Organic Fluid}

In this section, the results of the cost calculation for organic fluid collector/receiver systems are presented. The cost of each concept is taken from Section 3.0, Table 3-2.

\subsubsection{Performance Data for Organic Fluid}

The ranking index provides the relationship of cost and performance (efficiency). The concepts are being studied for use in a cogeneration system delivering electrical power and process heat. The analysis is performed under the condition that the same quantity of energy of each kind is used regardless of the thermal storage performance. The differences in efficiency for an alternative thermal storage concept are accounted as an increase (or decrease) in the quantity of purchased electricity and/or fuel (for process heat). The cost of these energy supplies, levelizing procedures, fixed charge rates, and the remaining economic parameters were taken from G.E. (1978). The data for that specific industry at the Shenandoah location are assumed to be fairly representative of the solar thermal cogeneration system user.

\section{Electrical Power Performance Data}

The analysis is similar to the one developed in Section 4.2.2. Three efficiencies of the thermal storage subsystem are required:

- First law (heat losses through insulation, etc; heat to heat);

- Second law (power-cycle conversion efficiency; heat to work); and

- Collector/receiver (insolation to heat).

Each efficiency is evaluated for each concept and divided by the same efficiency item for the reference concept. The three ratios are multiplied together for a single product. That product is presented in Table 4-4. The process is repeated for the same efficiency factors when operating direct (i.e., not through thermal storage).

For all of the concepts studied, the system always operates through storage, and thus the efficiency product through storage and direct are equal. When operating through storage all the time, the plant performance is not affected by the dispatch strategy. The rankings of the concepts are therefore not affected by the way the plant is used (or where it is located). The results, which are presented later in Section 4.3.4, are valid for all storage-use strategies. 
Table 4-4. PERPORMANCE DATA FOR CONCEPTS WITH ORGANIC FLUID RECEIVER

\begin{tabular}{|c|c|c|c|}
\hline Concept & $\begin{array}{c}\text { Product of } \\
\text { Efficiency } \\
\text { Ratios, } \\
\text { Storage }\end{array}$ & $\begin{array}{c}\text { Product of } \\
\text { Efficiency } \\
\text { Ratios, } \\
\text { Direct }\end{array}$ & Comments \\
\hline $\begin{array}{l}\text { Trickle Charge } \\
\text { Syltherm Taconite }\end{array}$ & 1.0 & 1.0 & Reference \\
\hline $\begin{array}{l}\text { Trickle Charge } \\
\text { Syltherm/Glass }\end{array}$ & 1.0 & 1.0 & Media charge only \\
\hline Phase Change $\mathrm{NaOH}$ & 0.5 & 0.5 & $\begin{array}{l}1 / 2 \text { of power required in } \\
\text { additional parasitics }\end{array}$ \\
\hline Molten Salt (K-Salt) & 0.965 & 0.965 & Cycle and parasities \\
\hline K-Salt/Glass & 0.965 & 0.965 & Cycle and parasitics \\
\hline
\end{tabular}

\section{Process Heat Performance Dàta}

The cogeneration system delivers process heat (and heat for building heating and absorption air conditioning) using extraction steam from the turbine. The steam conditions and flow rates delivered to the turbine for all of the concepts considered are almost identical. The performance factors for delivering low-temperature thermal energy were assumed to be equal. Also assumed equal were the quantities of process and building heat delivered by all of the thermal storage concepts; i.e., the amount of purchased fuel was equal for all concepts.

\subsubsection{Plänt Cost Breakdown}

Figure 4-6 presents the cost breakdown of the Shenandoah reference system employed in the ranking. All costs were calculated for an $n{ }^{\text {th }}$ commercial plant. The DOE cost goals were used for the solar collectors. Electric power plant costs were taken for the Shenandoah design (G.E. 1978). Levelized costing was employed for the purchased fuel and electricity with rates as reported for the Shenandoah facility. O\&M was also levelized over a 20-year plant life. The thermal storage is the reference trickle charge thermal storage. The energy plant includes field piping, heat exchanger to the steam system, low-temperature storage, valves, lines, cooling towers, and air conditioning equipment. All of these cost data were capitalized using the economic data reported for Shenandoah (G.E. 1978). 


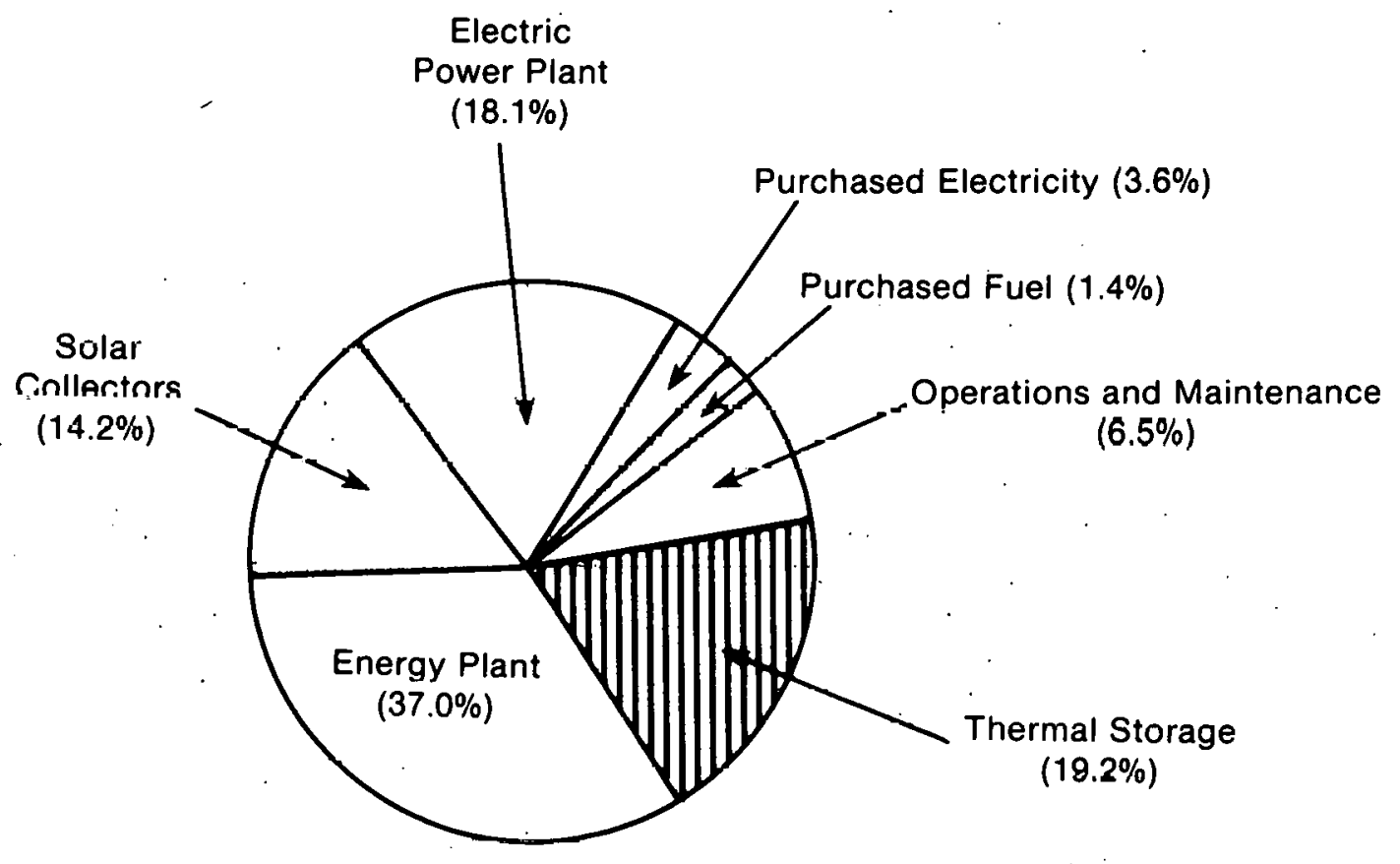

Figure 4-6. Cost Breakdown for Reference Organic Fluid Collector Receiver

(Fnr 192 Dishes. 10. Hours of Thermal Storage, Shenandoah Technology)

The data in Fig. 4-6 illustrate that the thermal storage represents $19 \%$ of the total energy syslem custs. The goals of the program are to rediuce the thermal storage subsystem cost by moro than 20\%. Because of the small contribution of thermal storage to the total cost, this goal is equivalent to a $4 \%$ reduction in the system cost.

\subsubsection{Comparison of Concepts}

The rankings of the thermal storage systems based on the energy system cost are presented in this section. The rankings were conducted for the design collector field area but with variable quantities of thermal storage. There is no effect of dispatch strategy on the rankings, because the concepts always operate through thermal storage. The effect of cost uncertainties is also analyzed. 


\section{Comparison with Variable Quantity of Storage}

Figure 4-7 presents the percent change in energy cost of a solar thermal/cogeneration system for the thermal storage concepts previously described. For the design conditions in Shenandoah, the concepts rank as follows:

\begin{tabular}{lcc}
\hline Concept & $\begin{array}{c}\text { Reduction in BBEC } \\
\text { of the System }\end{array}$ & $\begin{array}{c}\text { Equivalent Improvement in } \\
\text { Thermal Storage Costs }\end{array}$ \\
\hline Trickle Charge & $5.2 \%$ & $27 \%$ \\
Syltherm/Glass & $0 \%$ & $0 \%$ \\
K-Salt/Glass & $0 \%$ & $0 \%$ \\
Trickle Charge & & \\
Syltherm/Taconite & $0 \%$ & \\
\hline
\end{tabular}

The remaining concepts did not offer improvement. Of the above, only finding a lowercost medium (such as recycled glass) has the potential of meeting the program goals.

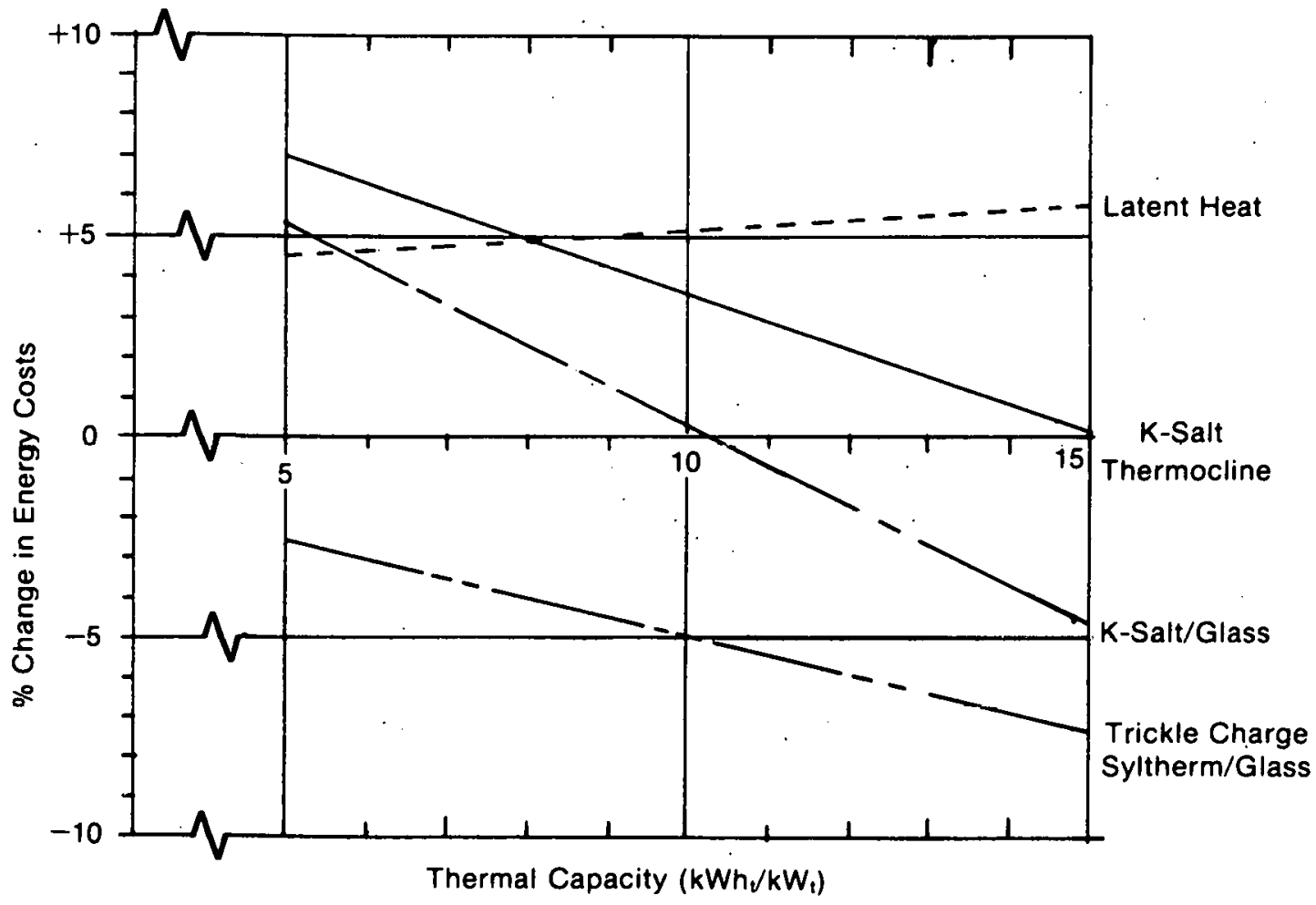

Figure 4-7. Comparison of Thermal Storage Concepts. Shenandoah Design 192, 7-Meter Dishes-10 Hours at $10 \mathrm{MBtu} / \mathrm{h}(2944 \mathrm{kWh})$ Trickle Charge Syltherm/Taconite Reference System 


\section{Comparison with $\pm 20 \%$ Variation in the Thermal Storage Subsystem Cost}

The design conditions for Shenandoah are for 192 dishes with 10 hours of storage. Under those conditions, the effect of a $\pm 20 \%$ variation in the thermal storage subsystem cost was analyzed. The objective was to test the results of the previous cost analysis, recognizing that there is uncertainty in the costs of the thermal storage concepts. Figure 4-8 presents the data. The top and bottom of each bar is the percent change in energy cost for that concept with a $\pm 20 \%$ cost variation.

Two concepts stand out as clearly undesirable: phase change and $\dot{K}$-salt. The $\mathrm{K}$-salt/glass concept is not noticeably better or worse than the reference system. The trickle charge Syltherm/glass concept offers a clear advantage over the reference system.

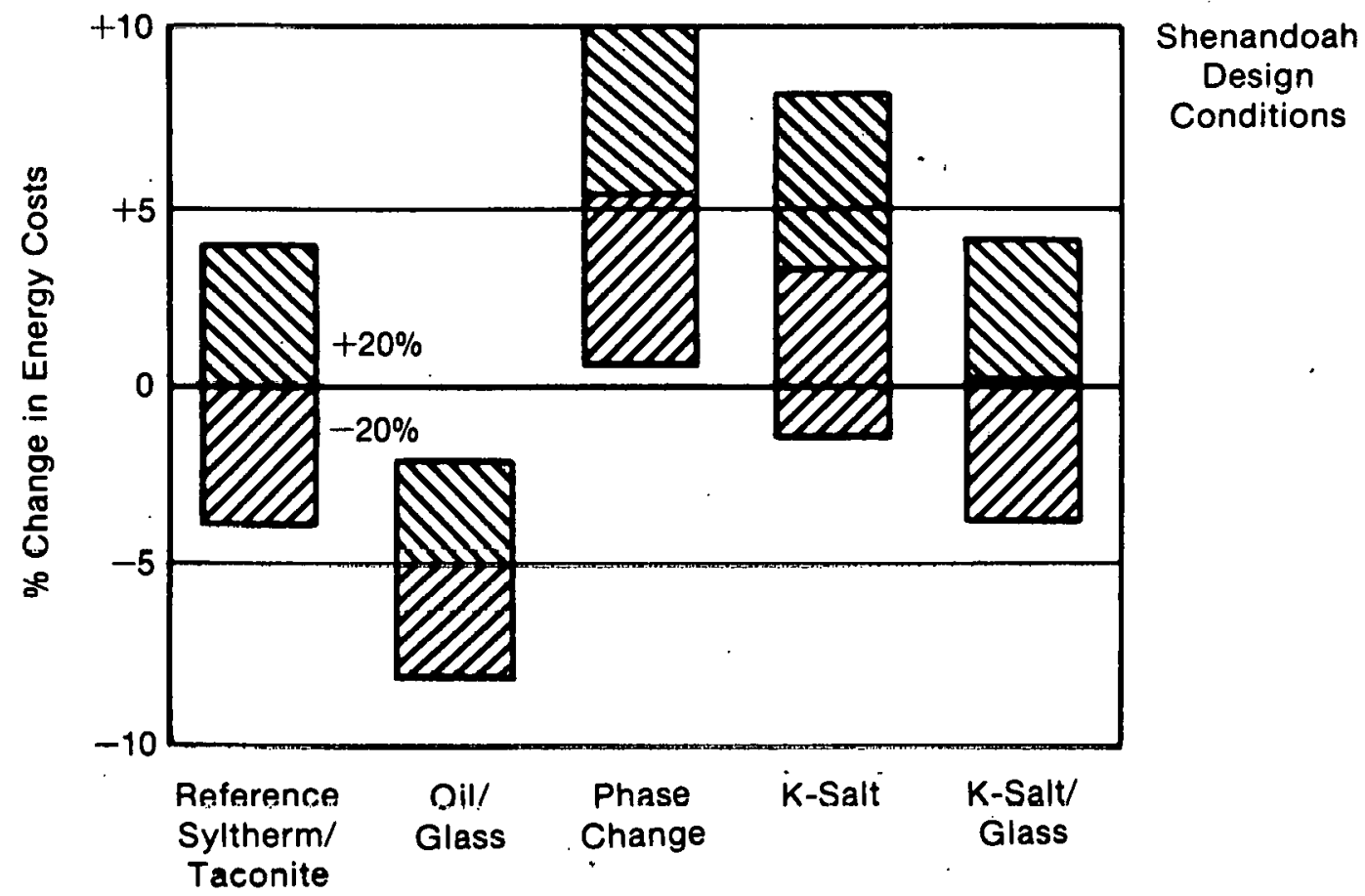

Figure 4-8. Comparison of Concepts with $\pm 20 \%$ Variation in Thermal Storage Subsystem Cost

(192 7-m Diametar Dishes, 10 hours of

Storage at $10 \mathrm{MBtu} / \mathrm{h}(2944 \mathrm{~kW})$ 
SECTION 5.0

CONCLUSIONS AND RECOMMENDATIONS

\subsection{CONCLUSIONS}

This study has analyzed a range of thermal storage concepts for two types of solar thermal collector/receiver system. Based on the data presented here, the following conclusions are reached:

Concepts with the Potential of Meeting Program Goals

- Water/Steam Collector/Receiver

- K-Salt/Glass (Buffer Storage Applications)

- Two Stage: Draw Salt/Glass and Oil/Rock

(Diurnal Storage Applications)

- Organic Fluid Collector/Receiver

- Trickle Charge Syltherm/Glass

Concepts That Would Increase the Energy System Costs

- Water/Steam Collector/Receiver

- Draw Salt

- Two-Stage Draw Salt and K-Salt

- $\mathrm{NaNO}_{3}$ Phase Change, Throttling

- Organic Fluid Collector/Receiver

- NaOH, Phase Change

- K-Salt

Concepts with Little or No Advantage or Penalty

- Water/Steam Collector/Receiver

- Impruved Phise Cliange, $\mathrm{NaNO}_{3}$

- Two-Stage Draw Salt/Glass and K-Salt/Glass

- Organic Fluid Collector/Receiver

- K-Salt/Glass

These conclusions are based solely on the concepts as described in this report. The above conclusions apply to other concepts only to the extent that they are representable by one of the analyzed concepts. Although one phase change concept was analyzed, the conclusions do not necessarily apply to other latent heat concepts.

The readers are cautioned that SERI made no judgment on the feasibility of any concept. Each concept was analyzed basically as described by the developer*; some of

*Although some modifications were made, the changes should not significantly influence the cost and performance data. 
the features of the concept are yet to be proven feasible. The analysis has taken the following viewpoint:

"Assuming that all development efforts are successful, which concepts offer the highest potential?"

The analyses of costs and performance were done on a consistent basis. The same cost data base and scaling algorithms were applied to all concepts. The rankings were done in a way that would isolate the effects due to each concept. The analysis was conducted over a range of storage capacities and collector field sizes. The effects on the conclusions of a cost uncertainty were also analyzed.

\subsection{OBSERVATIONS}

The following observations are not based on analyses but are an extrapolation of the da ta:

Water/Steam Collector Systems

- A replacement of the Caloria with a synthetic oil is not expected to offer either an improvement or a penalty; the reason is that a higher performance is accompanied by a much higher cost for the oil.

- Second-generation water/steam receivers may alter the conclusions. The higher temperature/pressure reheat receivers provide more energy at high temperatures, which can be stored effectively in the salt systems. This condition reduces the cost and improves the performance of the salt storage concepts. Because of its maximum temperature limit, the oil/rock system cannot be improved for second-generation water/steam receivers.

- The improved $\mathrm{NaNO}_{3}$ phase change system, as described herein, is one of the lowest cost latent heat systems compatible with a water/steam receiver system.

- Rocks are cheaper than chemicals. Whenever such materials can be used in a thermocline system, they will be more cost effective than a concept based solely upon refined or manuf actured chemicals.

\section{Organic Fluid Receiver Systems}

- The $\mathrm{NaOH}$ phase change system uses the same approach as the $\mathrm{NaNO}_{3}$ concepts in the water steam collector/receiver. SERI selected this system to minimize the analysis effort. The choice appears to be unfortunate. The high parasitic power losses impose very significant efficiency penalties. 'This fact becumes evident as a result of the analysis and was not anticipated a priori.

- Other phase change systems (such as Cohen et al. 1978) do not have the high parasitic losses, and the conclusion of this study should not be extrapolated to those other systems. The fact that other phase change systems arc different does not necessarily mean that they are better (or worse) than the one analyzed.

- The high cost of the taconite is due to the transportation charges and the cost of the medium. The availability of a lower cost, locally available, compatible solid medium is key to the reduction of the cost of the trickle charge concept. 
- Salt systems suffer a higher power-related cost due to the presence of an extra heat exchanger with an organic fluid collector/receiver system.

- A thermocline (not trickle charge) would be much higher cost than the Shenandoah system due to the high cost of the Syltherm.

\subsection{RECOMMENDATIONS}

\section{Thermal Storage for Water/Steam Collector Receiver}

- Research and development is recommended to find low-cost solid sensible heat media (on the order of $\$ 10$ to $\$ 20$ per ton, delivered) that are compatible with salts. Candidate materials include:

- Rocks

- Recycled glass

- Slag from coal-fired plants, steel mills, chemical plants, etc.

- If a low-cost solid medium is not found that is compatible with a salt(s), none of the concepts as defined herein offer the potential of meeting program goals. Development of one of those concepts is recommended only as a backup to minimize the risks inherent in any $R \& D$ program.

- Continuing, expanded development effort on the oil/rock system is recommended.

- Continued research in latent heat concepts is recommended. Such research should be directed to a simultaneous improvement in the power-related costs and parasitic power. The potential to reduce the energy-related costs should also be assessed.

\section{Thermal Storage for Organic Fluid Collector/Receivers}

- The reference thermal storage system Syltherm/taconite trickle charge is a good concept and continued development is recommended.

- Research and development is recommended on fluid compatibility for low-cost solid sensible heat media (rocks, recycled glass, slag, etc.).

- Development of a molten salt/low-cost medium concept is recommended as a backup to the Shenandoah thermal storage concept.

- Research is recommended to improve the latent heat concept with breakthroughs needed in power-related cost, parasitic power, and storage media costs.

- Additional cost and performance studies on other phase change concepts are recommended before any large-scale system development efforts begin on any latent heat system for this application. 


\section{SEP눈}




\section{SECTION 6.0}

\section{REFBRENCES}

Cohen, B. M.; Rice, R. E.; Rowny, P. E. 1978 (Dec.). Development of a Phase Change Thermal Storage System Using Modified Anhydrous Sodium Hydroxide for Electric Power Generation. DOE/NASA/0615-79/1. Cambridge, MA: Comstock and Wescott, Inc. (Contract NAS 3-20615).

Copeland, R. J. 1980 (April). Preliminary Requirements for Thermal Storage Subsystems in Solar Thermal Applications. SERI/RR-731-364. Golden, CO: Solar Energy Research Institute.

Department of Energy (DOE), U.S. 1979 (March 13). Thermal Energy Storage Technology Development for Solar Thermal Power Systems: Multiyear Program Plan. Washington, D.C.: Energy Storage Systems and Central Solar Technology Divisions.

Donabedian, M. 1978. Thermal Storage Cost/Temperature Tradeoff for Solar Total Energy Systems. Golden, CO: Thermal Storage Applications Workshop; pp. 139-168.

Electric Power Research Institute (EPRI). 1979 (July). Technical Assessment Guide. PS-120 1-SR. Palo Alto, CA.

Exxon Company. 1977. Caloria HT-43. Houston, TX.

General Electric Co. (G.E.). 1978 (July 10). Solar Total Energy - Large-Scale Experiment at Shenandoah, Georgia. 78-SDS-4234. G.E. Space Division. Philadelphia, PA.

Hallet, Raymond W.; Gervais, Robert L. 1977. Solar Thermal Power System Phase I, CRDL Item 2, Pilot Plant Preliminary Design Report. SAN/1108-8. Huntington Beach, CA: McDonnell Douglas Astronauties Company.

Hausz, W.; Berkowitz, B. J.; Hare, R. C. 1978 (Oct.). Conceptual Design of Thermal Energy Storage Systems for Near-Term Electric Utilities Applications. Vol. I. Screening of Concepts. DOE/NASA/0012-78/1. EPRI RP1082-1. NASA CR-159 411. GE78 TMP-60. Santa Barbara, CA: General Electric Co., Tempo Division.

Kreith, Frank. 1973. Principles of Heat Transfer. New York, NY: Harper and Row.

Lefrois, R. T.; Knowles, G. R.; Mathur, A. K.; Budimir, J. 1979 (Feb.). Active Heat Exchange System Development for Latent Heat Thermal Energy Storage. DOE/NASA/0038-7911. Minneapolis, MN: Honeywell, Corp.

Martin Marietta Corporation. 1978 (Sept.). Conceptual Design of Advanced Central Receiver Power System. EG-77-C-03-1724. Denver, CO.

McDonnell Douglas Astronautics Company. 1977 (May). Central Receiver Solar Thermal Power System Phase I, Preliminary Design Report. MDC G 6776. Hunting ton Beach, CA. 
..

Melton, W. C. 1978 (May 16). Performance, Value, and Cost of Solar Thermal Electric Central Receiver Plants Outside the Southwest. ATR-78 (7689-04)-1. El Segundo, CA: The Aerospace Corporation.

Sandia Laboratories, Livermore Report. 1977 (Oct.). Recommendations for the Conceptual Design of the Barstow, California, Solar Central Receiver Pilot Plant. SAND 77-8805. Livermore, CA. 


\begin{tabular}{|c|c|c|}
\hline $\begin{array}{c}\text { Document Control } \\
\text { Page }\end{array}$ & $\begin{array}{r}\text { 1. SERI Report No. } \\
\text { TR-631-647 }\end{array}$ & 3. Recipient's Accession No: \\
\hline \multirow{2}{*}{\multicolumn{2}{|c|}{$\begin{array}{l}\text { 4. Title and Subtitle } \\
\text { A Preliminary Screening of Thermal Storage Concepts } \\
\text { for Water/Steam and Organic Fluid Solar Thermal } \\
\text { Receiver Systems }\end{array}$}} & $\begin{array}{r}\text { 5. Publication Date } \\
\text { Apri1 } 1980 \\
\end{array}$ \\
\hline & & \\
\hline \multicolumn{2}{|c|}{ 7. Author(s) } & 8. Periorming Organization Rept. No. \\
\hline \multicolumn{2}{|c|}{ 9. Performing Organization Name and Address } & $\begin{array}{c}\text { 10. Project/Task/Work Unit No. } \\
3528.10\end{array}$ \\
\hline \multicolumn{2}{|c|}{$\begin{array}{l}\text { Solar Energy Research Institute } \\
1617 \text { Cole Boulevard } \\
\text { Golden, Colorado } 80401\end{array}$} & $\begin{array}{l}\text { 11. Contract (C) or Grant (G) No. } \\
\text { (C) } \\
\text { (G) }\end{array}$ \\
\hline \multirow{2}{*}{\multicolumn{2}{|c|}{ 12. Spọnsoring Organization Name and Address. }} & $\begin{array}{l}\text { 13. Type of Report \& Period Covered } \\
\text { Technical Report }\end{array}$ \\
\hline & & \\
\hline
\end{tabular}

15. Supplementary Notes

16. Abstract (Limit: 200 words)

A preliminary comparison of thermal storage concepts for solar thermal applications was done generically for large and small solar systems with sensible and latent heat and two-stage storage conepts. Concepts were ranked based on the cost of delivered energy. A $\pm 20 \%$ uncertainty in subsystem cost was included in the analysis. Water/steam and organic/fluid collector/receivers were studied separately. For the water/steam concept, Barstow technology (100 MW ) was examined. A nitrite/nitrate salt with a low-cost solid medium was best for buffer storage; for diurnal storage, the two-stage draw salt/lowcost media and oil/rock concept was best. Phase change concepts require improvements on the concept analized to be attractive. For the organic fluid system, a Shenandoah total energy system was examined. The Syltherm trickle charge taconite concept was the most favorable and may be improved by replacing the taconite with a lower-cost oil-compatible medium. Salt concepts can be competitive with this system only if there is a low-cost solid medium that is compatible with the salt and the end use requires a large amount of storage. The phase change concept examined was found to be quite poor for this total energy application.

17. Document Analysis

a. Descriptors Heat Storage ; Energy Storage ; Thermal Energy Storage Equipment ; Solar Thermal Power Plants; Solar Receivers; Water; Steam; Organic Compounds ; Molten Salts; Cost ; Performance

b. Identifiers/Open-Ended Terms

c. UC Categories

62

18. Availability Statement

National Technical Information Service

U. S. Department of Commerce

5285 Port Royal Road

Springfie $1 \mathrm{~d}$, Virginta 22161

19. No. of Pages

63

20. Price 